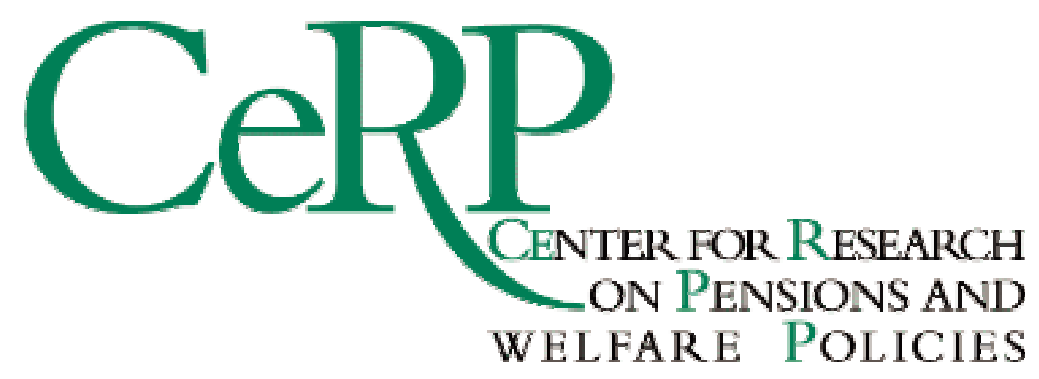

Working Paper 67/07

\title{
INTERNATIONAL DIVERSIFICATION AND LABOR INCOME RISK
}

\author{
Carolina Fugazza \\ Maela Giofré \\ Giovanna Nicodano
}

October 2007 


\title{
International diversification and labor income risk*
}

\author{
Carolina Fugazza ${ }^{\dagger}$ Maela Giofré ${ }^{\ddagger}$ and Giovanna Nicodano ${ }^{\dagger}$
}

October 24, 2007

\begin{abstract}
Members of an occupational pension plan face the same industry shocks, since membership is based on employment industry. An occupational pension fund may therefore design portfolio composition so as to hedge members' labour income shocks at the industry level. This paper quantifies differences in optimal equity portfolios across investors belonging to different industry-country pairs. We compare these industry-based portfolios to the one that would be optimal for an investor endowed with the average home-country labor income. Our analysis uncovers remarkable heterogeneity across industries in the three investing countries considered - US, Canada and Italy. These results point to a clear-cut role of occupational pension funds in hedging labour income risk through international equity diversification.
\end{abstract}

JEL: E44, G11, G15

Keywords: optimal portfolio choice, labor income risk, industry-specific human capital, occupational pension funds

\footnotetext{
${ }^{*}$ We thank Fabio Bagliano, Onorato Castellino, Frank De Jong, Elsa Fornero, Massimo Guidolin, Roel Mehlkopf and participants at CIEF Meeting, Nestpar Workshop and Collegio Carlo Alberto seminar. Financial support from Rotman International Centre for Pension Management, University of Toronto, and Netspar is gratefully aknowledged. Any errors or omissions are responsibility of the authors.

${ }^{\dagger}$ Università di Torino and Center for Research of Pensions and Welfare Policies (CeRP)-Collegio Carlo Alberto (CCA); e-mail: fugazza@cerp.unito.it; giovanna.nicodano@unito.it.

${ }^{\ddagger}$ CeRP-CCA; e-mail: giofre@cerp.unito.it
} 


\section{Introduction}

The benefits from international diversification of equity portfolios have been documented long ago (Grubel, 1968; Levy and Sarnat, 1970) and persist despite increased stock market integration (De Santis and Gerard, 1997). It is also well known that human capital affects optimal portfolio composition (Merton, 1971; Mayers, 1972) which hedges labor income risk. This paper assesses how this risk affects optimal equity diversification of workers.

We focus in particular on industry risk within each country. Our choice derives from the magnitude and stability of interindustry wage differentials in the US (Dickens and Katz, 1987a,b; Krueger and Summers, 1987, 1988; Katz and Summers, 1989; Weinberg, 2001), which points to the importance of the industry factor in the labor income process. International comparisons confirm this pattern in many OECD countries (Gittleman and Wolff, 1993; Kahn 1998) ${ }^{1}$. Moreover, wage shocks at the industry and aggregate level display a different cyclical pattern (Blanchard and Fischer, 1989; Solon, Barsky, and Parker, 1992).

Against this background, this paper quantifies differences in optimal equity portfolios across investors belonging to different industry-country pairs in the period 1998-2004. In particular, we compute the optimal behavior of US, Canadian and Italian investors working in seven different industries, from Financials to Manufacturing, who invest in the stock indices of ten destination countries including their own. We compare these industry based portfolios to the national restricted portfolio, i.e. the one that would be optimal for an investor endowed with the average home-country labor income.

This comparison provides insights on how occupational pension funds ${ }^{2}$ may differentiate their investment strategies from those of open-end pension funds ${ }^{3}$. Members in any given occupational plan plausibly face the same industry shocks, since membership is based on their employment industry. On the contrary, participants in open-end pension fund belong to different industries. An occupational pension fund may therefore design portfolio composition so as to hedge shocks to its own industry, while open-end pension funds can only hedge national income shocks. Thus, if the correlation between shocks to French equity and shocks to wages in US manufacturing is higher than that of the average US worker, then US pension funds for manufacturing workers ought to demand less French stocks relative to the national restricted portfolio. Clearly, this tailored allocation is valuable to the extent that shocks differ across industries so that optimal allocations do as well.

Overall, our analysis uncovers remarkable heterogeneity across industries in the three investing countries pointing to a clear-cut role of occupational pension funds. For instance, according to our results, hedging labor income risk at industry level induces optimal investment in UK ranging from -0.15 to 0.16 for US, from -0.04 to 0.29 for Canada and from -0.19 to 0.30 for Italy. Moreover, absolute distances between industry and national restricted portfolio weights range from a minimum of 0.04 to 0.37 for US, from 0.03 to 0.87 for Canada, and from 0.03 to 0.26 for

\footnotetext{
${ }^{1}$ Gittleman and Wolff (1993) use data on fourteen countries confirming the existence of wage differentials which increased between 1970 and 1985.

${ }^{2}$ Pension funds' assets represent a large fraction of households' wealth in most countries: the percentage of pension funds assets on GDP is $95 \%$ for US, $52 \%$ for Canada and $3 \%$ for Italy (Source: OECD, Global Pension Statistics 2004)

${ }^{3}$ Refer to Defined Contribution (DC) plans, where contributions are fixed proportions of participants' salary and benefits depend on returns on the plan's portfolio. Thus financial risk is borne by the participant.
} 
Italy and the percentage of statistically different labor income components across industry pairs is $48 \%$ for the US, $44 \%$ for Canada and $28 \%$ for Italy.

Our paper builds on the Adler and Dumas (1983) model where investors in any given country consume the same bundle of goods and hence face the same inflation risk. Their optimal portfolios hedge deviations from the world inflation rate, implying that the market portfolio is not universally efficient as investors choose different risky portfolios according to their own country. For instance, a Canadian investor would allocate a higher weight to Dutch stocks if the covariance of Dutch equity returns with Canadian inflation were higher than the world average inflation covariance. Here, we retain the assumption that workers in any given country face the same inflation risk and also allow for heterogeneous labor income induced by being employed in different industries. Consequently, optimal stock portfolios also hedge the deviation of an industry in a given country from world income growth. Thus, a Canadian investor working in the banking sector would allocate a higher weight to Dutch stocks if the covariance of Dutch equity returns with wages in the Canadian banking sector is lower than the world average wage covariance.

Our data evidence that, for the three countries considered, the labor hedging motive is stronger than the inflation hedging one. Cross country comparison reveals that both hedging motives appear to be stronger in US and Canada than in Italy. In particular, the lower degree of heterogeneity across Italian industry-specific portfolios and the small size of the aggregate labor hedging component lead us to conjecture that workers' protection may contribute to smooth the impact of wage shocks and weakening their linkages with financial shocks.

This type of analysis connects our paper to the literature on the so called "home bias puzzle", consisting in a disproportionate actual investment in domestic assets with respect to the weight of domestic assets in the market portfolio. The latter ought to be the optimal risky portfolio according to the International CAPM. Clearly, such large holdings of domestic assets could be rational if domestic equities are a better hedge of country-specific risks, such as deviations from the purchasing power parity or risks connected with non traded assets. Cooper and Kaplanis (1994) do not support the inflation hedging motive as an explanation of the home bias. Baxter and Jermann (1997) find a quasi-perfect positive correlation among domestic returns to human and physical capital, which should induce a short position in domestic assets - widening the home bias. On the contrary, Bottazzi et al. (1996) argue that accounting for human capital reduces by about 30\% (on average in OECD countries) the bias towards domestic assets. They confirm that human capital returns have positive correlation with physical capital. But they also find a negative correlation with financial returns, which reduces the home bias. Coën (2001) accounts for both inflation and national labor income hedging motives finding that both are negligible and cannot therefore explain it.

According to our results, hedging income risk at the industry level still cannot explain the "home bias puzzle": the domestic equity holdings observed in actual portfolios are still higher than our equilibrium allocations. More precisely, accounting for industry-based risk reduces the home bias in Canada and the US while it increases it in Italy. However, Baxter and Jermann (1997)'s prescription of going short in domestic assets holds only for Italy ${ }^{4}$. In US we find that

\footnotetext{
${ }^{4}$ Julliard (2003), relying on the same dataset as in Baxter and Jermann (1997) but under a more comprehensive econometric setting which relies also on Bayesian techniques, finds that the inclusion of human capital does not unequivocally worsen the puzzle and in some cases helps explaining it.
} 
accounting for both the labor and the inflation hedging effects lead to an optimal long position in domestic asset (0.36), albeit lower than its market share (0.42). For Canada and Italy, the optimal position in domestic equities are 0.09 and -0.01 respectively.

In line with our approach, recent work by Eiling (2006) documents that the inclusion of industry-specific human capital greatly improves the empirical performance of both the static and the conditional CAPM. In particular, she finds that labor income growth systematically explains stock returns ${ }^{5}$.

The effect of heterogeneous labor income on optimal portfolio composition has been already investigated in a life-cycle model (Cocco et al, 2005), which also nicely characterizes permanent and transitory shocks in individual wage profiles. Despite our dynamic set up, our portfolio choice rule turns out to be myopic as in similar consumption and portfolio decisions with constant investment opportunities (Merton, 1971). As a consequence, we simply use the rate of growth in per capita labor income to measure returns to human capital and its realized volatility to proxy for risk, following a common practice in the financial literature ${ }^{6}$. In both models, optimal portfolio choice rests on the correlation structure of financial asset returns and labor income when labor supply is inelastic but they study a domestic asset allocation problem while we focus on international diversification. Importantly, Cocco et al. (2005) study individual optimal behavior in a partial equilibrium model, while we focus on equilibrium equity allocations.

This paper is structured as follows. In section 2 we describe the theoretical setting. Section 3 reports details on data and econometric methods. In section 4 we discuss our empirical results. Section 5 concludes.

\section{The model}

\section{$2.1 \quad$ The setup}

We now derive optimal equity portfolios extending Cooper and Kaplanis (1994) and Coën (2001) to industry-specific human capital. We consider a representative investor living in home country $l$ and working in industry $s$, who chooses among $N$ country stock indexes and 1 risk-free asset. She maximizes a time-additive, constant relative risk aversion utility function over life-time consumption expenditures. The objective function for the investor $s l$ is:

$$
\underset{C^{s l} ; w^{s l}}{\operatorname{ax}} E \int_{t}^{T} V\left(C^{s l}, P^{l}, \tau\right) d \tau
$$

where $C^{s l}$ is her nominal rate of consumption expenditures, $w^{s l}$ denotes the $N \times 1$ vector containing investor's portfolio weights on the available equity indexes, $P^{l}$ is the price index and $V($.$) is the instantaneous rate of (indirect) { }^{7}$ utility, which is homogeneous of degree zero in $C^{s l}$ and $P^{l}$.

\footnotetext{
${ }^{5}$ She finds that the performance of the static CAPM improves the adjusted $R^{2}$ of estimated equations by $6 \%$ when aggregate human capital is included and by $36 \%$ when industry specific human capital is considered.

${ }^{6}$ For instance, Jagannathan and Wang (1996) provide support for the conditional CAPM with human capital by approximating its returns with the growth rate in per capita income.

${ }^{7}$ Adler and Dumas (1983) provide details on the maximization problem in presence of a price index instead of a set of commodity prices.
} 
The instantaneous rate of return on the equity index of country $j(j=1, \ldots, N)$, expressed in the measurement currency, follows the stationary Ito process

$$
d Y_{j} / Y_{j}=\mu_{j} d t+\sigma_{j} d z_{j}
$$

where $Y_{j}$ denotes the market value of equity index $j ; \mu_{j}$ and $\sigma_{j}$ represent the instantaneous expectation and standard deviation of the nominal rate of return on the equity index $j, z_{j}$ is a standard Wiener process and $d z_{j}$ is the associated white noise process.

The price index $P_{l}$ follows the stationary Ito process

$$
d P^{l} / P^{l}=\pi^{l} d t+\sigma_{\pi}^{l} d z_{\pi}^{l}
$$

where $\pi^{l}$ and $\sigma_{\pi}^{l}$ are the instantaneous expectation and standard deviation of the inflation rate faced by investor in country $l, z_{\pi}^{l}$ is a standard Wiener process and $d z_{\pi}^{l}$ is the associated white noise process.

The return on human capital for the investor working in industry $s$ in country $l$, expressed in the measurement currency, follows the stationary Ito process

$$
d H^{s l} / H^{s l}=h^{s l} d t+\sigma_{h}^{s l} d z_{h}^{s l}
$$

where $H^{s l}$ is human capital in terms of the measurement currency, $h^{s l}$ and $\sigma_{h}^{s l}$ are the instantaneous expectation and standard deviation of the nominal rate of change of wage, $z_{h}^{s l}$ and $d z_{h}^{s l}$ are a standard Wiener process and the associated white noise process respectively.

Each investor is assumed to receive $(1-\eta)$ of his total income from financial income and $\eta$ from income related to human capital ${ }^{8}$. Then the wealth dynamics are:

$d W^{s l}=(1-\eta)\left\{\left[\sum_{j=1}^{N} w_{j}^{s l}\left(\mu_{j}-r\right)+r\right] W^{s l} d t+\sum_{j=1}^{N} w_{j}^{s l} \sigma_{j} W^{s l} d z_{j}\right\}+\eta\left\{h^{s l} W^{s l} d t+\sigma_{h}^{s l} W^{s l} d z_{h}^{s l}\right\}-C^{s l} d t$

where $W^{s l}$ denotes the investor's nominal wealth and $w_{j}^{s l}$ is the portfolio share invested in country $j$ equities. The reader can recognize in the first curly bracket the portfolio return, and in the second bracket the return on human capital.

We denote by $J(W, P, t)$ the maximum value of the instantaneous expected utility subject to the wealth accumulation constraint, obtained by solving the problem with the Bellman principle. We also denote by $\lambda$

$$
\lambda=-\frac{J_{W W}}{J_{W}} W
$$

the common investor's relative risk aversion coefficient where $J_{W}$ and $J_{W W}$ are, respectively, the first and second partial derivative of $J($.$) with respect to W$.

\footnotetext{
${ }^{8}$ Campbell (1996) also imposes this assumption in an asset pricing model, ensuring that income distribution between factor of production is constant. Friend, Lanskrones and Losq (1976) impose a constant ratio of human wealth over total wealth in a portfolio choice problem.
} 


\subsection{Optimal portfolio choice}

From the solution of the problem ${ }^{9}$, the nominal risk premium on equity index $j$ is:

$$
\mu_{j}-r=\left[\sigma_{j \pi}^{l}(1-\lambda)\right]+\lambda\left[(1-\eta) \sum_{k=1}^{N} w_{k}^{s l} \sigma_{j k}+\eta \sigma_{j h}^{s l}\right]
$$

where $\sigma_{j \pi}^{l}$ is the covariance between returns on stock index $j$ and the inflation rate in country $l ; \sigma_{j k}$ is the covariance between returns on assets $j$ and $k$; and $\sigma_{j h}^{s l}$ is the covariance between returns on asset $j$ and the labor income growth in sector $s$ in country $l$.

The equity portfolio of investor $\{s l\}$ is, therefore:

$$
\mathbf{w}^{s l}=\boldsymbol{\Omega}^{-1}\left\{\frac{\frac{1}{\lambda}}{(1-\eta)}[\boldsymbol{\mu}-r \mathbf{i}]+\frac{\left(1-\frac{1}{\lambda}\right)}{(1-\eta)} \varpi^{l}-\frac{\eta}{(1-\eta)} \boldsymbol{\kappa}^{s l}\right\}
$$

where $\mathbf{i}$ is a $N$-vector of ones, $\Omega$ is a $(N x N)$ matrix of instantaneous variances-covariances $\sigma_{j k}$ of nominal rates of return on equity indexes, $\varpi^{l}$ is a $N$-vector of covariances $\sigma_{j \pi}^{l}$ between nominal equity return in country $j$ and country l's rate of inflation and $\boldsymbol{\kappa}^{\text {sl }}$ is a $N$-vector of covariances $\sigma_{j h}^{s l}$ between nominal equity return $j$ and investor $s l$ 's labor income growth.

The optimal portfolio can be decomposed into three parts. The first is the usual myopic portfolio which is common to all investors since it only depends upon the joint distribution of equity returns. The share demanded in the $j$-th stock index increases in $j$-th excess return, and falls in its contribution to overall risk. The second term is the country specific hedge portfolio of Adler and Dumas (1983). When relative risk aversion exceeds 1 , the portfolio share of $j$-th stock index increases if the correlation between country $l$ inflation and $j$-th nominal returns is positive. This ensures that the $j$-th stock index is a good hedge against increases in the price of country $l$ consumption goods. The third is the industry-country specific hedge portfolio built to hedge labor income risk. We maintain that investors who work in the same industry and country face common labor income risk. Consequently they share the same hedging portfolio against this type of risk. The portfolio share of $j$-th stock index increases if the correlation between wage risk in industry $s$ in country $l$ has negative correlation with the $j$-th nominal return. If the correlation between each industry wage of country $l$ and the $j$-th nominal return is equal, then we obtain the optimal portfolio composition of Coën (2001). Clearly, the optimal portfolio coincides with the myopic portfolio for all investors when investors' specific background risks are neglected.

More precisely, in the particular case, of $\eta=0$ there is no labor income and the optimal portfolio reduces to the Adler and Dumas (1983) formulation in which there is only the inflationhedging component in addition to the logarithmic one. Furthermore, if the investor's risk aversion is equal to one $(\lambda=1)$, then the inflation-hedging component is null and the optimal portfolio reduces to the logarithmic one common to all investors.

It should now become clear why the choice of which labor income to hedge is extremely relevant. Wages may be acyclical at industry level, while they tend to be cyclical at the country level (Blanchard and Fischer, 1989; Solon, Barsky, and Parker, 1992). Thus considering the

\footnotetext{
${ }^{9}$ See Appendix A for details on the derivation.
} 
correlations between aggregate wages - as opposed to industry wages - and stock returns is likely to imply very different portfolio strategies.

\subsection{Equilibrium}

We apply the market clearing condition, requiring that the vector of equity supply in the $\mathrm{N}$ countries equal the vector of equity demand ${ }^{10}$. When both vectors are expressed as shares, we have:

$$
\mathbf{M S}=\sum_{s l} v^{s l} \mathbf{w}^{s l}
$$

where MS is the market portfolio, i.e. the vector of shares of each equity market over total world capitalization, and $v^{s l}$ represents the wealth of industry $s$ in country $l$ as a fraction of total world wealth (accordingly, $v^{l}$ represents the wealth of country $l$ as a fraction of total world wealth). Substituting (7) into (8) we obtain the following equilibrium condition:

$$
\mathbf{M S}=\boldsymbol{\Omega}^{-1}\left[\frac{\frac{1}{\lambda}}{(1-\eta)}(\boldsymbol{\mu}-r \mathbf{i})+\frac{\left(1-\frac{1}{\lambda}\right)}{(1-\eta)} \sum_{l} v^{l} \varpi^{l}-\frac{\eta}{(1-\eta)} \sum_{s l} v^{s l} \kappa^{s l}\right]
$$

Substituting the market clearing condition back into the equity portfolio we can rewrite the final equilibrium portfolio as:

$$
\mathbf{w}^{s l}=\mathbf{M S}+\frac{\left(1-\frac{1}{\lambda}\right)}{(1-\eta)} \mathbf{\Omega}^{-1}\left[\left(\varpi^{l}-\sum_{l} v^{l} \varpi^{l}\right)\right]-\frac{\eta}{(1-\eta)} \boldsymbol{\Omega}^{-1}\left[\left(\boldsymbol{\kappa}^{s l}-\sum_{s l} v^{s l} \kappa^{s l}\right)\right]
$$

where $\sum_{l} v^{l} \varpi^{l}$ captures the average world covariance between country inflation rates and equity returns, while $\sum_{s l} v^{s l} \kappa^{s l}$ measures the average world covariance between industry labor income and equity returns. In equilibrium investor sl optimal portfolio is made of the market portfolio, which is universally efficient if background risks are neglected, and two hedging components.

The first hedging component indicates that investor sl's allocation to equity $j$ is higher than the $j$-th market share when the covariance of the $j$-th return with country $l$ inflation is higher than the world average inflation covariance. The second hedging component indicates that investor $s l$ 's allocation to equity $j$ is higher the lower is the covariance between the $j$-th return and wage growth in industry $s l$ with respect to the world average wage covariance.

Equation (9) can also be used in order to derive equilibrium risk premia. The inflation and labor income hedging demands affect the equilibrium equity premia, leading to a reformulation of the International CAPM (Adler and Dumas,1983) with industry specific human capital. In a recent work, Eiling (2006), derives the so-called human capital CAPM providing an explanation to the observed premium to the idiosyncratic risk. In particular, she finds evidence of the ability of human capital returns (at the industry level) to account for a large portion of observed returns. While this evidence is in line with our approach, we do not pursue asset pricing issues and focus on portfolio implications.

\footnotetext{
${ }^{10}$ The following condition says that the net supply of bonds is zero and of equities is the capitalization of the relevant equity market.
} 


\subsection{Implications}

The first implication of the model concerns the role of occupational pension funds. Assume that wage growth rates in all the industries in country $l$ exhibit the same comovement with the index return $j$, i.e.:

$$
\operatorname{cov}\left(h^{s l}, R_{j}\right)=\operatorname{cov}\left(h^{l}, R_{j}\right) \quad \forall s
$$

where $h^{s l}$ is the wage growth rate prevailing in industry $s$ country $l, h^{l}$ is the average wage growth in country $l$ and $R_{j}$ is the nominal return on equity index $j$. Then we would obtain that:

$$
\mathbf{w}^{s l}=\mathbf{w}^{l} \quad \forall s
$$

i.e. the portfolio composition $\mathbf{w}^{l}$ is optimal for all industries in country $l^{11}$. When (12) holds, the portfolio suitable to hedge risks attached the average national labor income in country $l$ (that we call the "national restricted portfolio") is also optimal for hedging labor income risks at industry level $s l$. Consequently, there is no difference in the equity portfolio of occupational pension funds and open-end pension funds. If (12) does not hold, then there is scope for delineating optimal investment strategies suitable to hedge labor income risk at the industry level - a specific role for occupational pension funds.

A second implication concerns the home bias puzzle, defined in the literature as the difference between actual and equilibrium position of country $l$ in its own domestic equity market. In previous work, where restriction (12) is implicitly imposed, the relevant covariance is the one with human capital returns at the national level. Baxter and Jermann (1997) find a quasi perfect positive correlation with domestic assets that leads to an equilibrium short position on them widening the "home bias". The negative correlation found by Bottazzi et al. (1996), using a different sample period and a different econometric model, leads to an optimal long position in domestic assets which reduces the home bias. In our framework, the equilibrium position in domestic equity, and hence the home bias, is the result of the aggregation of industry specific portfolios, which in turn depend on the covariance between industry specific wage growth rates and the returns on equity. Below we assess whether relaxing (12) reduces the home bias, by juxtaposing the aggregate industry specific portfolios $\sum_{s} \nu^{s l} \mathbf{w}^{s l}$, which we call the "national unrestricted portfolio", to the national restricted one obtained by imposing $(12)^{12}$.

\section{Empirical Analysis: Data and Methodology}

\subsection{Data}

We consider three investing countries -US, Canada and Italy- for which monthly data on wages at industry level are available from January 1997 to December 2004. Data are drawn for the US from the Current Employment Statistics, for Canada from the Survey of Employment, Payrolls and

\footnotetext{
${ }^{11}$ In this case, our model replicates Coen (2001) where all risks are country specific.

${ }^{12}$ We define as "national restricted portfolio" the optimal portfolio suitable to hedge risks attached to the average labor income process.
} 
Hours and for Italy from Retribuzioni e Lavoro, ISTAT. The coarser industry level disaggregation for the Italian labor markets forces us to consider only seven industries within each of these three countries: Financials, Leisure, Manufacturing, Trade, Transports and Communications, Utilities, Other Services.

US data series on wages at monthly frequencies are longer than for Italy and Canada, where labor statistics are observable since 1996 and 1997, respectively. In order to preserve comparability of results among the three countries considered we rely on the shortest sample. From monthly data over 1997:01 - 2004:12, for a total of 96 observations, we derive 84 overlapping annual observations on the corresponding growth rates prevailing over 1998:01 to 2004:12. We thus have enough information to consistently estimate the relationship of wage growth and inflation rates with financial returns ${ }^{13}$.

Annual stock market capitalization and total returns -in local currencies- are drawn from Datastream Equity Indexes for ten destination countries: Canada, France, Germany, Italy, Japan, Netherlands, Sweden, United Kingdom, United States, Rest of the World. In the empirical implementation we maintain that investors completely hedge exchange rate risk and keep all returns follow a fully hedging strategy, i.e. we keep all variables expressed in local currencies ${ }^{14}$.

Finally, inflation rates are based on CPI indices from the IMF International Financial Statistics.

In Table 1 we report the mean and standard deviations of nominal industry wage growths in the three investing countries from which it can be evidenced that they are comparable across the three countries. Importantly, heterogeneity across industries emerges when considering correlations of industry nominal wages with the respective national wage growth in Table 2. Over the whole sample period, US correlations range from -0.33 to 0.80 , from -0.42 to 0.73 for Canada and from 0.01 to 0.73 for Italy, evidencing a lower degree of heterogeneity in Italy.

Table 3 displays the mean and standard deviation of stock returns for the ten destination countries so as to complete the overview of the relevant variables.

\subsection{Methodology}

In order to compute the equilibrium allocations in (10), we directly observe in the data the vector of market shares $M S$. The coefficients $\lambda$ and $\eta$ are exogenous parameters. In our simulations we consider alternative values for the coefficient of relative risk aversion $\lambda$ in the range $\{2,10\}$, as commonly proposed by the literature ${ }^{15}$. The parameter $\eta$ is set equal to is the world average labor share $(0.63)^{16}$. The term $\Omega^{-1}\left[\left(\varpi^{l}-\sum_{l} v^{l} \varpi^{l}\right)\right]$ can be directly measured from historical data. However, following Cooper and Kaplanis (1994), it can also be estimated through a regression analysis. Indeed, it coincides with the vector $b^{l}$ of coefficients of the multiple regression of $\left(p^{l}-\sum_{l} v^{l} p^{l}\right)$, where $p^{l}$ the inflation rate of country $l$, on the vector of realized nominal returns $R$.

\footnotetext{
${ }^{13}$ In the next section we discuss how we correct for the induced autocorrelation in residuals.

${ }^{14}$ This assumption is common in the literature (Baxter and Jermann, 1997).

${ }^{15}$ Our findings on portfolio compositions are similar under different degrees of risk aversion. So we report results only for the case of risk aversion equal to five.

${ }^{16}$ Campbell (1996) suggests that the ratio of human wealth to total wealth is about two-thirds, since $2 / 3$ of the national GDP goes to labor. The choice about a specific level of $\eta$, however, should even a priori not significantly affect our conclusions about the heterogeneity of optimal portfolios across industries.
} 


$$
\Omega^{-1}\left(\varpi^{l}-\sum_{l} v^{l} \varpi^{l}\right)=\mathbf{b}^{l} \equiv\left(\begin{array}{c}
b_{1}^{l} \\
\vdots \\
b_{j}^{l} \\
\vdots \\
b_{N}^{l}
\end{array}\right)
$$

Similarly, the labor income component, $\boldsymbol{\Omega}^{-1}\left(\boldsymbol{\kappa}^{s l}-\sum_{s l} v^{s l} \boldsymbol{\kappa}^{s l}\right)$ coincides with the vector of coefficients, $q^{s l}$, of the multiple regression of $\left(x^{s l}-\sum_{s l}^{S, L} v^{s l} x^{s l}\right)$ onto the vector of realized nominal returns $R$, where $x^{s l}$ is the rate of change of labor income in industry $s$-country $l^{17}$. For each country $l$, we also obtain the $q_{l}$ hedging coefficients to compute the national restricted portfolio. Thus, we also run a regression where the dependent variable is the deviation of the average national wage rate from the average world wage rate. This will be compared with the national unrestricted portfolio ${ }^{18}$

$$
\boldsymbol{\Omega}^{-1}\left(\kappa^{s l}-\sum_{s, l} v^{s l} \boldsymbol{\kappa}^{s l}\right)=\mathbf{q}^{s l} \equiv\left(\begin{array}{c}
q_{1}^{s l} \\
\vdots \\
q_{j}^{s l} \\
\vdots \\
q_{N}^{s l}
\end{array}\right)
$$

Under this new notation, the $j$-th element of the vector of equilibrium allocations in (10) is equal to:

$$
w_{j}^{s l}=M S_{j}+\frac{\left(1-\frac{1}{\lambda}\right)}{(1-\eta)} b_{j}^{l}-\frac{\eta}{(1-\eta)} q_{j}^{s l}
$$

In the above regressions we proxy the wealth shares $\left(v^{l}\right)$ with the market shares $\left(M S^{l}\right)$ as common practice in the literature (Cooper and Kaplanis, 1994, Adler and Dumas, 1983). Contemporaneous returns are instrumented with lagged returns, and estimation is performed through $\mathrm{GMM}^{19}$. We thus run one regression for each country $l$ to obtain the inflation hedging coefficient $b^{l}(13)$ :

\footnotetext{
${ }^{17}$ The relation between human capital and tradable assets is investigated in several studies: Lustig and Van Nieuwerburgh (2006) find a negative correlation between innovations on human capital and stock returns. According to Davis and Willlen (2000) human capital returns are correlated with both size and industry based portfolios while the correlation with aggregate equities is week. Moreover, a number of recent works focuses also on the predictability of stock returns through labor income.

${ }^{18}$ The national unrestricted portfolios are obtained as the weigthed sum of all optimal industry portfolios. In the aggregation, the relative weight $\nu^{s l}$ of industry $s$ in country $l$ is measured by $\frac{\text { labor income } e_{s l}}{\sum_{s} \text { labor income } e_{s l}}$, where labor income $_{s l}$ is the total labor income compensation paid in industry $s l$. Thus, they are the country portfolios that obtain by aggregating across industries the industry-based portfolios within each country.

${ }^{19}$ We have also alternatively conducted a Three-Stages-Least-Squares estimation: we have estimated within a system all equations for the inflation hedging coefficient and for labor hedging coefficients in all industries. The estimated coefficients are unaffected and the standard errors do not significantly alter results with respect to the case of applying directly the GMM method to the system, so we opt for this latter as it provides robust standard errors of estimates.
} 


$$
\left(p^{l}-\sum_{l} M S^{l} p^{l}\right)_{t}=b_{0}^{l}+\sum_{j=1}^{J} b_{j}^{l} R_{j, t}+\varepsilon_{t}^{l}
$$

and one regression for each industry $s, l$ to obtain the industry specific labor income hedging coefficient $q_{s, l}(14)$ :

$$
\left(x^{s l}-\sum_{s l} M S^{s l} x^{s l}\right)_{t}=q_{0}^{s l}+\sum_{j=1}^{J} q_{i}^{s l} R_{i, t}+v_{t}^{s l}
$$

In our analysis, we investigate the ability of financial returns to hedge inflation and labor income risks at annual frequency. We use monthly observations on overlapping annual equity returns, wage growth and inflation rates so to have enough information to consistently estimate parameters. We correct for the induced serial correlations in the errors ${ }^{20}$ with the Newey-West method to obtain consistent standard errors.

\section{Empirical Analysis: Results}

In this section we present the equilibrium allocations constructed as in (10) by estimating, as specified above, the hedging coefficients $b^{l}$ and $q^{s l}$ in regressions (13) and (14). We focus on intermediate risk aversion $(\lambda=5)$, as results obtained under other parametric assumption are similar.

The resulting portfolio compositions at industry level, $w^{s l}$, are reported in Panel (a) of Tables from 4 to 6 , columns 1 to 7 . Column 8 reports the national unrestricted portfolio obtained as the weighted sum of all optimal industry portfolios. Column 9 displays the national restricted portfolios obtained when restriction (12) is imposed and the equilibrium allocation hedges the country-level background risk. Column 10 reports, for reference, the vector of market shares $M S$ of the destination countries: if neither the inflation hedging nor the labor income hedging are important then the optimal portfolio will be equal to the market share of the considered destination countries.

We then compute again equity allocations when considering only the statistically significant (at ten percent confidence level) hedging coefficients $b_{j}^{l}$ and $q_{j}^{s l}$. We set to zero the non significant ones, therefore imposing that the corresponding labor (or inflation) hedging portfolio weight is null. We show these results in Panel (b) of Tables 4-6. In our comments, we will mostly refer to the latter estimates, as they are - if anything - biased against our conjecture that hedging labor income risk at industry level is relevant.

Columns 1 to 7 in Table 4 show that, in each investing country, industry specific allocations are quite different from each other. Workers in Manufacturing invest 0.50 of their portfolio in US equity (above the US market share, $M S_{U S}$ ), shorting German shares (-0.12) (clearly below the German market share, $\left.M S_{G E}\right)$. On the contrary, a US worker in the Leisure industry holds in US equity a share lower than $M S_{U S}(0.28)$ and higher than $M S_{G E}(0.09)$. These patterns can

\footnotetext{
${ }^{20}$ Boudoukh and Richardson (1993), among others, apply the same correction when looking at the inflationstock returns regression with overlapping returns.
} 
be traced back to $q_{U S}^{\operatorname{man}, U S}$ relative to $q_{U S}^{\text {leis,US }}$. Indeed, it is the case that the correlation of wage growth in US Leisure (Manufacturing) with US equity is higher (lower) than the world average wage correlation. The opposite holds for correlations with German equity returns.

The range of domestic investment is 0.0 - 0.24 for Canadian industries (see Table 5) and is -0.18 to 0.02 for Italian industries (Table 6).

In Canada, workers in Trade are long in Dutch shares (0.20) but should short in UK shares (-0.04) while those in Transport would short Dutch shares (-0.20) and long UK equity (0.24). In Italy, heterogeneity across industries is smaller and does not seem to be confined to Euro-area stock indexes ${ }^{21}$.

Heterogeneity across industry portfolios is mirrored also in the fraction each industry optimally invests in the risk free asset, ranging from -0.15 to 0.17 for US, from -0.47 to -0.19 for Canada and from -0.10 to 0.22 for Italy.

In the following sections we check whether these preliminary observations hold true. We first scrutinize the size of inflation and labor income hedging components (4.1) and then the heterogeneity of the optimal portfolio compositions across different industries, which provides insight on the role of occupational pension funds (4.2).

\subsection{The relevance of hedging motives}

Tables 4-6 say very little about the relevance of different hedging components across industries. As the distance between $M S$ and the industry portfolios could be associated with small labor hedging components and large inflation ones, or vice versa, in this section we focus on the relative importance of the two.

We report the weight of the labor hedging component across industries in each country in Tables 7a-9a, while in Tables 7b-9b we display the weight of the labor income hedging portfolio relative to the market share at industry level. They reveal heterogeneity across industries in each country even when considering only "significant" portfolios. Looking at domestic positions, the relative importance of the labor hedging component ranges from -0.24 to 0.28 in the US, in Canada from -3.28 to 4.54 and in Italy from -8.29 to -7.87 . More precisely, from Table $7 \mathrm{~b}$ we see that, for labor income hedging scope, domestic equities ought to enter positively in the optimal portfolio for the US Manufacturing industry while they should be shorted by four industries and disregarded by two. The relative labor hedging component in German equities ranges from -6.43 for the US Transportation investing industry to 9.72 for the US Utilities investing industry ${ }^{22}$. Tables 8b shows that a higher degree of heterogeneity is present among optimal industry portfolios in Canada, although few hedging coefficients are significant. Compared with US and Canada, the overall degree of heterogeneity among Italian industry portfolios is rather low, also considering the fact that few stock indices should be held for labor hedging purposes by a small number of investing industries. In order to hedge the labor income risk, only two investing industries (ITA Financials and ITA Transport) should optimally hedge labor income risk through a remarkable equity diversification (by investing at least in four out of ten destination countries considered), and three destination countries indices should be totally disregarded for labor hedging by all

\footnotetext{
${ }^{21}$ We conjecture that workers' protection may better shield them from industry specific wage shocks.

${ }^{22}$ The corresponding range in terms of the labor hedging component, i.e. not rescaled by the market share (see Table $7 \mathrm{a})$, is from -0.23 to 0.34 .
} 
industries.

Column 9 of each table reports the inflation hedging component which is common to all industries in a country. Our findings about the role of stocks in hedging inflation risks are mixed. For US five out of ten destination country indices turn out to have no significant inflation hedging role and domestic equities should be optimally shorted. For Canadian investors six destination country indices are significantly useful to hedge the inflation risk with a long position in the domestic equities. Finally, for Italy investing in stocks plays a little role in hedging inflation risk: eight stock indices, among which domestic equities, are not significantly correlated with domestic inflation.

Column 8 of Tables 7-9 evidences the labor hedging component in the national unrestricted portfolio, obtained by aggregating the labor hedging components at industry level weighted by labor income compensation. Values in Columns 8 and 9 sum up to the total hedging component in the national unrestricted portfolio (Column 10). The total hedging component may be interpreted as the optimal demand, due to hedging motives, expressed by all industries in a country. For all the three countries considered, labor hedging prevails on inflation hedging in determining departure of the optimal aggregate demand from the $M S$.

However, this perspective underestimates the size of the labor hedging motive in individual (industry-specific) portfolios, as positive and negative positions offset in the aggregation procedure. In Tables 10 we provide a more correct measure of the size of the labor hedging motive, that is the weighted average - across industries- of the absolute values of labor hedging components, by destination countries (Columns 3 and 4). Columns 1 and 2 display, by destination stock indices, the absolute value (size) of the inflation hedging components. The last row in each panel reports the sum of the (absolute) hedging components for all destination countries, that is, by each source of hedged risk (inflation or labor income), we derive the sum of the (absolute) portfolio positions specifically designed to hedge that kind of risk. Comparison between Column 2 and 4, referred to significant coefficients only, evidences that for all the three investing countries considered the labor hedging motive is stronger than the inflation hedging one. Cross country comparison reveals that both hedging motives appear to be stronger in US and Canada than Italy $^{23}$.

Column 5 and 6 of Table 10 report the absolute value of the labor hedging component in the national restricted portfolio. Columns 6 and 4 show how ignoring heterogeneity across industries induces an improper evaluation of the labor hedging motive, as the weighted average of the size of labor hedging (Column 4) across industries dominates the size of the labor hedging in the national restricted portfolio (Column 6).

This result highlights that heterogeneity across industry matters. In the following section we test the robustness of the heterogeneity of labor hedging components across industries and their departure from the national restricted portfolio.

\footnotetext{
${ }^{23}$ The low labor hedging size for Italy supports our conjecture about the impact of workers' protection in smoothing wage shocks and possibly weakening the linkage with financial shocks.
} 


\subsection{The role of occupational pension funds: hedging industry-specific labor income risk}

So far we maintain the assumption that restriction (12) does not hold. We now test the equality of labor income hedging coefficients across investing industries $\left(q_{j}^{s l}\right)$ by estimating the regressions (16) and (17) for the seven industries within the same country in a system. The result of this test sheds light on the relevance of industry wage risk. Consequently, it reveals whether there is scope for hedging labor income risk at industry level through industry-specific portfolios. The null hypothesis of the Wald test we perform is the following

$$
\text { Ho: } q_{i \in S}^{i l}=\underset{\substack{q_{j}^{s l} \\ s \in S, s \neq i}}{q_{i \in t}}
$$

where $S$ is the set of investing industries.

We provide a graphical representation of the result of this test, hence of the difference among the industry-based portfolios. For each and every pair of industries within a country, we count the number of significantly different coefficients. Since we have seven industries, we consider 21 possible pairs for each country. For each of these 21 couples we count the number of significantly different labor hedging portfolio component. For instance, we check whether the shares invested in Japanese stock by US worker in the trade and in the leisure industry are statistically different. We repeat this test for the other nine destination countries.

Figure 1-3 associate the number of statistically different coefficient on the horizontal axis to the number of industry-pairs on the vertical axis. Thus there are eight industry-pairs out of 21 that differ in five portfolio shares out of ten in the US. In Canada five industry-pairs out of 21 differ by seven portfolio weights out of ten. In Italy six industry-pairs differ by two portfolio weights. The subtitle to each graph reports the number of statistically different coefficients as a percentage of 210 (21 pairs times 10 coefficients, one for each destination country). This is $48 \%$ for the US, $44 \%$ for Canada and $28 \%$ for Italy. Thus, it appears that in the US and Canada an industry- tailored portfolio designed by occupational pension funds would be most valuable.

Last but not least, we perform a Wald test on the difference between the industry specific labor hedging coefficient, $q_{j}^{i l}$, and the national restricted one, $q_{j}^{l}$.

$$
H o: q_{s \in S}^{s l}=q_{j}^{l}
$$

Table 11 reports the statistically significant absolute distances between industry $\left(w^{s l}\right)$ and national restricted portfolio weights $\left(w^{l}\right)$. We find that such distances are large. The widest range, from 0.03 to 0.87 , is observed for Canada, being 0.04-0.37 for US and 0.03-0.26 for Italy. Moreover, the number of statistically significant distances is highest for US and least for Italy, confirming that industry-tailored portfolios are most useful to the US and Canada.

Finally, Table 12 reports portfolio dispersion measures derived over industry portfolios shown in Tables 4, 5 and 6. Table 12.I and 12.II report the measures of dispersion of optimal equity

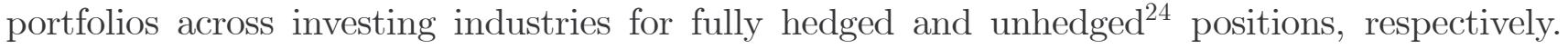
Panel (a) displays the standard deviation of differences between industry portfolios from the

\footnotetext{
${ }^{24}$ For each investing industry, unhedged positions are computed on series expressed in the home -currency.
} 
national restricted portfolio in the corresponding country ${ }^{25}$. These are computed weighting each difference with either the industry labor compensation (weighted) or with equal weights (unweighted). In table 12.I this is equal to 32 percentage points (pp) in the US, $42 \mathrm{pp}$ for Canada and $22 \mathrm{pp}$ for Italy, when we account for statistically significant weighted differences. The dispersion measures increase to $36 \mathrm{pp}$ for the US, $56 \mathrm{pp}$ for Canada and $25 \mathrm{pp}$ for Italy when industries are equally weighted. Thus, it appears that industries with a smaller relative labor income compensation should command portfolio shares that are more distant from the national restricted one.

Panel (b) displays the standard deviation of industry portfolio weights assigned to each destination country $\left(w_{j}^{s l}\right)$ evaluated with respect to the corresponding weight in the national restricted portfolio $\left(w^{l}\right)^{26}$. The standard weighted deviation is $10 \mathrm{pp}$ for US, $13 \mathrm{pp}$ for Canada and $7 \mathrm{pp}$ for Italy. Table 12.II reports these measures of dispersion computed under the assumption that exchange rate risk is unhedged. Though the unhedged optimal portfolio compositions ${ }^{27}$ differ substantially from fully-hedged ones, results about heterogeneity across industry portfolios are qualitatively similar.

The extent of heterogeneity in labor income across industries, and hence the role of occupational pension funds appear to be robust independently of the metric used. They consistently appear more marked in the US and Canada than in Italy.

\section{Conclusions}

Households often fail to attain their objectives in financial decision planning (Campbell, 2006) and institutional investors may help cope with these failures (Bodie, 2002). As pension funds' assets represent a large fraction of households' wealth in most countries, tracing precise connections between their investment strategies and households' risk exposure is crucial. We find that the labor income hedging components are sizeable in seven industries of three countries. Our study also uncovers substantial heterogeneity in equity allocations across industries. This indicates that occupational pension funds have a role in diversifying households' background risk. This role is especially pronounced for Canada and the US. This pattern could be ascribed to workers' protection in Italy. If this conjecture is correct, the role of occupational pension funds would be reduced in countries where labor protection already dampens industry wage shocks. In order to provide further evidence on this, the cross-sectional dimension of our data set should be widened. Unfortunately these types of data are unavailable in other countries to our knowledge.

This paper focusses on international diversification of equity portfolios. Clearly, a further step of this analysis may assess the relative merits of international diversification versus inter-industry diversification.

Our analysis required covering several industries and countries at once. This forced us to use an industry classification that does not necessarily coincide with that of occupational pension funds, due to data availability. Moreover, we used equity indexes that are not necessarily traded

\footnotetext{
${ }^{25}$ The measures of dispersion are derived computing standard measures of variability but computed around the national restricted portfolio rather than around the mean. Reported measures are derived, alternatively, on all distances and on only significant distances.

${ }^{26}$ The measures of dispersion are explained in detail in Table 12.

${ }^{27}$ Not reported here, but available upon request.
} 
in the marketplace. These limits can be easily circumvented in practical implementations that focus on one industry at a time. Some of our simplifying assumptions which make the model more tractable, such as that of no short sale constraints, can also be relaxed where necessary. 


\section{References}

[1] Abowd, J. M., Kramarz, F. and D. N. Margolis (1999), "High wages workers and high wage firms", Econometrica, 67, 252-333.

[2] Adler, M. and B. Dumas (1983), "International Portfolio Choice and Corporation Finance: A Synthesis", Journal of Finance, 38, 925-984.

[3] Baxter, M. and U. J. Jermann (1997). "The International Diversification Puzzle Is Worse Than You Think", American Economic Review, 87(1), 170-80.

[4] Baxter, M., U.J. Jermann and R.G. King (1998), "Nontraded Goods, Nontraded Factors, and International Non-Diversification", Journal of International Economics, 44, 212-229.

[5] Blanchard, O. and S. Fisher (1989), Lectures on Macroeconomics, Cambridge MA: MIT Press.

[6] Bodie, Z., R. C. Merton and W. Samuelson (1992), "Labor supply flexibility and portfolio choice in a life cycle model", Journal of Economic Dynamics and Control, 16, 427-449.

[7] Bodie, Z. (2002), "Life-Cycle Finance in Theory and in Practice", Boston University School of Management Working Paper No. 2002-02.

[8] Bottazzi, L, P. Pesenti and E. van Wincoop (1996), "Wages, Profits, and the International Portfolio Puzzle", European Economic Review, 40 (6), 219-254.

[9] Boudoukh, J., and R. Matthew (1993), "Stock Returns and Inflation: A Long-Horizon Perspective", American Economic Review, 83 (5), 1346-1355.

[10] Brainard, W. C., J. B., Shoven and L. Weiss (1980), "The Financial Valuation of the Return to Capital", Brookings Papers on Economic Activity 2, 453-511.

[11] Campbell, J.Y. (1996), "Understanding Risk and Return", Journal of Political Economy, 104 (2), 298-345.

[12] Campbell, J. Y. (2006), "Household Finance", Journal of Finance, 61, 1553-1604.

[13] Campbell, J. Y. and R. J. Shiller (1988), "Stock Prices, Earnings and Expected Dividends", Journal of Finance, 3, 661-76.

[14] Campbell, J. Y. and L. M. Viceira (2002), Strategic Asset Allocation, Oxford University Press, New York.

[15] Cocco, J. F., F. J. Gomes and P. J. Maenhout (2005), "Consumption and Portfolio Choice over the Life Cycle", Review of Financial Studies, 2005 18, 491-533.

[16] Coën, A. (2001), "Home bias and International Capital Asset Pricing Model with Human Capital", Journal of Multinational Financial Management, 11, 497-513. 
[17] Cooper, I. A. and E. Kaplanis (1994), "Home Bias in Equity Portfolios. Inflation Hedging and International Capital Market Equilibrium", Review of Financial Studies, 7, 45-60.

[18] Davis, S.J. and P. Willen (2000), "Occupation-Level Income Shocks and Asset Returns: their Covariance and Implications for Portfolio Choice", NBER Working Paper No Wr905

[19] De Santis, G. and B. Gerard (1997), "International Asset Pricing and Portfolio Diversification with Time-Varying Risk", Journal of Finance, 52, 1881-1912.

[20] Dickens, W. T. and L. F. Katz (1987a), "Inter-Industry Wage Differences and Industry Characteristics" in Lang K. and Leonard J. (eds), Unemployment and the Structure of Labor Markets, Basil Blackwell, Oxford.

[21] Dickens, W. T. and L. F. Katz (1987b), "Interindustry wage differences and Theories of Wage Determination", NBER Working Paper No 2271.

[22] Eiling, E. (2006), "Can Nontradable Assets Explain the Apparent Premium for Idiosyncratic Risk? The Case of Industry-specific Human Capital", Working paper, Tilburg University.

[23] Fama, E.F. and G.W. Schwert (1977), "Human Capital and Capital Market Equilibrium", Journal of Financial Economics, 4, 95-125.

[24] French, K. and J. Poterba (1991), "Investor Diversification and International Equity Markets", American Economic Review, 81, 222-226.

[25] Friend, I., Y. Landskroner and E. Losq (1976), "The Demand for Risky Assets under Uncertain Inflation", Journal of Finance, 31, 1287-1298.

[26] Gittleman, M. and E. N. Wolff (1993), "International Comparison of Inter-Industry Wage Differentials", Review of Income and Wealth, 39, 295-312.

[27] Grauer, R. and H.N. Hakansson (1987), "Gains From International Diversification 1968-1985 Returns on Portfolios of Stocks and Bonds", Journal of Finance, 42(3), 721-741.

[28] Griffin, J. and G. Karolyi (1998), "Another look at the role of industrial structure of markets for international diversification strategies", Journal of Financial Economics, 50, 351-373.

[29] Grubel, H. (1968), "International Diversified Portfolios: Welfare Gains and Capital Flows", American Economic Review, 58, 1299-1314.

[30] Heaton, J. and D. Lucas (2000), "Portfolio choice and asset prices: The importance of entrepreneurial risk", Journal of Finance, 55, 1163-1198.

[31] Jagannathan, R. and Z. Wang, (1996) "The Conditional CAPM and the Cross-Section of Expected Returns", Journal of Finance, 51, 3-53.

[32] Julliard, C. (2003),. "The international diversification puzzle is not worse than you think", International Finance 0301004, EconWPA. 
[33] Kahn, L. M. (1998), "Collective Bargaining and the Inter-Industry Wage Structure: International Evidence", Economica, 65, 507-534.

[34] Katz, L. F. and L. H. Summers (1989). "Industry Rents: Evidence and Implications", Brookings Papers on Economic Activity: Microeconomics, 209-275.

[35] Krueger, A. B. and L. H. Summers (1987) "Reflection on the Inter-Industry Wage Structure", in Lang K. and Leonard J. (eds), Unemployment and the Structure of Labor Markets, Basil Blackwell, Oxford.

[36] Krueger, A. B. and L. H. Summers (1988). "Efficiency Wages and the Inter-Industry Wage Structure", Econometrica, 56, 259-293.

[37] Levy, H. and M. Sarnat (1970), "International Diversification in Investment Portfolios", American Economic Review, 60, 668-675.

[38] Lewis, K.K. (1999), "Trying to Explain Home Bias in Equities and Consumption" Journal of Economic Literature, 37(2), 571-608.

[39] Lustig, H.N. and S.G. van Nieuwerburgh (2005), "Housing Collateral, Consumption Insurance and Risk Premia: an Empirical Perspective", Journal of Finance, 60 (3), 1167-1219.

[40] Mayers, D., (1972), "Non-Marketable Assets and the Capital Market Equilibrium Under Uncertainty", in Jensen, ed, Studies in the Theory of Capital Markets, Praeger, New York, $223-248$

[41] Merton, R.C. (1971), "Optimum Consumption and Portfolio Rules in a Continuous-Time Model", Econometrica, 41, 867-87.

[42] Palacios-Huerta, I. (2001), "The Human Capital of Stockholders and the International Diversification Puzzle", Journal of International Economics, 54, 309-31.

[43] Sercu, P. (1980), "A Generalization of the International Asset Pricing Model", Revue de l'Association Française de Finance,1, 91-135.

[44] Solnik, B. H. (1974), "An Equilibrium Model of the International Capital Market", Journal of Economic Theory, 8, 500-524.

[45] Solon, G., R. B. Barsky and J. A. Parker (1992) "Measuring the Cyclicality of Real Wages: How Important is Composition Bias", NBER Working Paper No W4202

[46] Sorensen, B. E., Y. Wu, O. Yosha and Y. Zhu (2007), "Home Bias and International Risk Sharing: Twin Puzzles Separated at Birth", Journal of International Money and Finance, forthcoming.

[47] Viceira, L. M. (2001), "Optimal Portfolio Choice for Long-Horizon Investors With Nontradable Labor Income", Journal of Finance 56, 433-470.

[48] Weinberg, B. A. (2001), "Long-Term Wage Fluctuations with Industry-Specific Human Capital", Journal of Labor Economics, 1. 231-264. 


\section{A Appendix: Optimal Portfolios}

$$
\begin{gathered}
\underset{C^{s l}, w^{s l}}{\operatorname{Max}} E \int_{t}^{T} V\left(C^{s l}, P^{l}, \tau\right) d \tau \\
d W^{s l}=(1-\eta)\left[\sum_{j=1}^{N} w_{j}^{s l}\left(\mu_{j}-r\right)+r\right] W d t+\eta h^{s l} W d t-C^{s l} d t+(1-\eta) \sum_{j=1}^{N} w_{j}^{s l} \sigma_{j} W d z_{j}+\eta \sigma_{h}^{s l} W d z_{h}^{s l}
\end{gathered}
$$

We provide details on the derivation of the optimal portfolio rule. For simplicity we drop the subscript the subscript $s, l$ and rewrite $\sigma_{h}^{s l}$ as $\sigma_{h}$. Therefore the covariance between the labor income process and the stock return $j$ is indicated as $\sigma_{j, h}$ and the covariance between the labor income process and the inflation rate is indicated as $\sigma_{\pi, h}$ and the covariance between stock return $j$ and the inflation rate is denoted as $\sigma_{j, \pi}$

Denoting by $J(W, P, t)$ the maximum value of (4) subject to (5) the Bellman principle states that its total expected rate of increase must be equal to zero:

$$
\begin{aligned}
& 0=\underset{C^{s l}, w^{s l}}{M a x}\left[V\left(C^{s l}, P^{l}, \tau\right)+J_{t}+J_{W}\left\{\left[(1-\eta)\left[\sum_{j=1}^{N} w_{j}^{s l}\left(\mu_{j}-r\right)+r\right]+\eta h^{s l}\right] W^{s l}-C^{s l}\right\}+\right. \\
& +J_{P} P^{l} \pi^{l}+\frac{1}{2} J_{W, W}\left\{(1-\eta)^{2} \sum_{j=1}^{N} \sum_{k=1}^{N} w_{j}^{s l} w_{k}^{s l} \sigma_{j, k}+\eta^{2}\left(\sigma_{h}^{s l}\right)^{2}+2 \eta(1-\eta) \sum_{j=1}^{N} w_{j}^{s l} \sigma_{j h}^{s l}\right\}\left(W^{s l}\right)^{2}+ \\
& \left.+\frac{1}{2} J_{P P}\left(\sigma_{\pi}^{l}\right)^{2} P^{2}+J_{W, P}\left\{(1-\eta) \sum_{j=1}^{N} w_{j}^{s l} \sigma_{j \pi}^{l}+\eta \sigma_{\pi h}^{s l}\right\} W^{s l} P^{l}\right]
\end{aligned}
$$

The homogeneity of degree 0 of the function $V(C, P, \tau)$ implies that $J(W, P, t)$ satisfying 22 be homogeneous of degree zero in $W$ and $P$ and therefore by Euler's theorem

$$
\begin{aligned}
& J_{P} \equiv-(W / P) J_{W} \\
& J_{P, W} \equiv-(1 / P) J_{W}-(W / P) J_{W, W} \\
& J_{P, P} \equiv 2\left(W / P^{2}\right) J_{W}+(W / P)^{2} J_{W, W}
\end{aligned}
$$

Substituting into the previous expression

$$
\begin{aligned}
& 0=\underset{C^{s l}, w^{s l}}{\operatorname{Max}}\left[V\left(C^{s l}, P^{l}, \tau\right)+J_{t}+J_{W}\left\{\left[(1-\eta)\left[\sum_{j=1}^{N} w_{j}^{s l}\left(\mu_{j}-r\right)+r\right]+\eta h^{s l}\right] W^{s l}-C^{s l}\right\}+\right. \\
& \left.-\frac{W^{s l}}{P^{l}} J_{W} P^{l} \pi+\frac{1}{2} J_{W, W}(1-\eta)^{2} \sum_{j=1}^{N} \sum_{k=1}^{N} w_{j}^{s l} w_{k}^{s l} \sigma_{j, k}+\eta^{2}\left(\sigma^{s l}\right)^{2}+2 \eta(1-\eta) \sum_{j=1}^{N} w_{j}^{s l} \sigma_{j h}^{s l}\right\}\left(W^{s l}\right)^{2}+ \\
& +\frac{1}{2}\left[2\left(W^{s l} / P^{l 2}\right) J_{W}+\left(W^{s l} / P^{l 2}\right) J_{W, W}\right]\left(\sigma_{\pi}^{l}\right)^{2}\left(P^{l}\right)^{2}+ \\
& \left.+\left[-\left(1 / P^{l}\right) J_{W}-\left(W^{s l} / P^{l}\right) J_{W, W}\right]\left\{(1-\eta) \sum_{j=1}^{N} w_{j}^{s l} \sigma_{j \pi}^{l}+\eta \sigma_{\pi h}^{s l}\right\} W^{s l} P^{l}\right] \\
& 0=\underset{C^{s l}, w^{s l}}{M a x}\left[V\left(C^{s l}, P^{l}, \tau\right)+J_{t}+J_{W}\left\{\left[(1-\eta)\left[\sum_{j=1}^{N} w_{j}^{s l}\left(\mu_{j}-r\right)+r\right]+\eta h^{s l}\right] W^{s l}-C^{s l}\right\}+\right. \\
& -J_{W} \pi W^{s l}+\frac{1}{2} J_{W, W}\left\{(1-\eta)^{2} \sum_{j=1}^{N} \sum_{k=1}^{N} w_{j}^{s l} w_{k}^{s l} \sigma_{j, k}+\eta^{2}\left(\sigma_{h}^{s l}\right)^{2}+2 \eta(1-\eta) \sum_{j=1}^{N} w_{j}^{s l} \sigma_{j h}^{s l}\right\}\left(W^{s l}\right)^{2}+ \\
& +J_{W}\left(\sigma_{\pi}^{l}\right)^{2} W^{s l}+\frac{1}{2} J_{W, W}\left(\sigma_{\pi}^{l}\right)^{2}\left(W^{s l}\right)^{2}-J_{W}(1-\eta) \sum_{j=1}^{N} w_{j}^{s l} \sigma_{j \pi}^{l} W^{s l}-J_{W} \eta \sigma_{\pi h}^{s l} W^{s l}+ \\
& \left.-J_{W, W}(1-\eta) \sum_{j=1}^{N} w_{j}^{s l} \sigma_{j \pi}^{l} W^{2}-J_{W, W} \eta \sigma_{\pi h}^{s l}\left(W^{s l}\right)^{2}\right]
\end{aligned}
$$




$$
\begin{aligned}
& 0=\underset{C^{s l}, w^{s l}}{\operatorname{Max}}\left[V\left(C^{s l}, P^{l}, \tau\right)+J_{t}+J_{W}\left\{( 1 - \eta ) \left[\left[\sum_{j=1}^{N} w_{j}^{s l}\left(\mu_{j}-r\right)+r\right]+\eta h^{s l}-\pi^{l}+\left(\sigma_{\pi}^{l}\right)^{2}+\right.\right.\right. \\
& \left.\left.-(1-\eta) \sum_{j=1}^{N} w_{j}^{s l} \sigma_{j \pi}^{l}+-\eta \sigma_{\pi h}^{s l}\right] W^{s l}-C^{s l}\right\}+\frac{1}{2} J_{W, W}\left\{(1-\eta)^{2} \sum_{j=1}^{N} \sum_{k=1}^{N} w_{j}^{s l} w_{k}^{s l} \sigma_{j, k}+\right. \\
& \left.\left.+\eta^{2}\left(\sigma_{h}^{s l}\right)^{2}+2 \eta(1-\eta) \sum_{j=1}^{N} w_{j}^{s l} \sigma_{j h}^{s l}+\left(\sigma_{\pi}^{l}\right)^{2}+-2(1-\eta) \sum_{j=1}^{N} w_{j}^{s l} \sigma_{j \pi}^{l}-2 \eta \sigma_{\pi h}^{s l}\right\}\left(W^{s l}\right)^{2}\right]
\end{aligned}
$$

The derivatives with respect to $C^{s l}$ and $w_{j}^{s l}$ are set equal to zero to obtain FOC with respect to consumption: $V_{C}=J_{W}$ and FOC with respect to portfolio weights $w_{j}$ :

$$
\begin{aligned}
& 0=J_{W}\left[(1-\eta)\left(\mu_{j}-r\right)-(1-\eta) \sigma_{j \pi}^{s l}\right] W^{s l}+\frac{1}{2} J_{W, W}\left[2(1-\eta)^{2} \sum_{k=1}^{N} w_{k}^{s l} \sigma_{j, k}+\right. \\
& \left.+2 \eta(1-\eta) \sum_{k=1}^{N} \sigma_{j h}^{s l}-2(1-\eta) \sum_{j=1}^{N} \sigma_{j \pi}^{l}\right]\left(W^{s l}\right)^{2} \\
& 0=J_{W}\left[\left(\mu_{j}-r\right)-\sigma_{j \pi}^{l}\right]+J_{W, W}\left[(1-\eta) \sum_{k=1}^{N} w_{k}^{s l} \sigma_{j, k}+\eta \sum_{j=1}^{N} \sigma_{j h}^{s l}-\sum_{j=1}^{N} \sigma_{j \pi}^{l}\right] W^{s l}
\end{aligned}
$$

Defining as $-\frac{J_{W W}}{J_{W}} W=\lambda$ the investor relative risk aversion, we derive the nominal risk premium (6)on security $j$

$$
\begin{aligned}
& \left(\mu_{j}-r\right)=\lambda\left[(1-\eta) \sum_{k=1}^{N} w_{k}^{s l} \sigma_{j, k}+\eta \sigma_{j h}^{s l}-\sigma_{j \pi}^{l}\right]+\sigma_{j \pi}^{l}= \\
& =\lambda\left[(1-\eta) \sum_{k=1}^{N} w_{k}^{s l} \sigma_{j, k}+\eta \sigma_{j h}^{s l}\right]+(1-\lambda) \sigma_{j \pi}^{l}
\end{aligned}
$$

or, in vector notation for all securities,

$$
(\boldsymbol{\mu}-r \mathbf{i})=\lambda\left[(1-\eta) \Omega \mathbf{w}^{s l}+\eta \boldsymbol{\kappa}^{s l}\right]+(1-\lambda) \varpi^{l}
$$

where $\mathbf{i}$ is a $N x 1$ vector of ones, $\boldsymbol{\mu}$ is the vector of nominal expected returns $\mu_{j}, \boldsymbol{\Omega}$ is the $N x N$ matrix of instantaneous covariances $\sigma_{j, k}$ of the nominal rates, $\varpi^{l}$ is the $N x 1$ vector of covariances $\sigma_{j \pi}^{l}$ of the $N$ risky securities returns with the investor's rate of inflation, $\boldsymbol{\kappa}^{s l}$ is the $N x 1$ vector of covariances $\sigma_{j h}^{s l}$ of the $N$ risky securities returns with the investor's rate of wage growth.

Consistently with Adler and Dumas (1983) and Coën (2001), (29) shows how the equity premium required by investor $s l$ is linked to its background risks. Solving for the optimal portfolio weights

$$
\mathbf{w}^{s l}=\frac{\frac{1}{\lambda}}{(1-\eta)} \boldsymbol{\Omega}^{-1}(\boldsymbol{\mu}-r \mathbf{i})+\frac{\left(1-\frac{1}{\lambda}\right)}{(1-\eta)} \boldsymbol{\Omega}^{-1} \varpi^{l}-\frac{\eta}{(1-\eta)} \boldsymbol{\Omega}^{-1} \boldsymbol{\kappa}^{s l}
$$

By considering also the $(N+1)$-th weight, that is the risk-free asset, we derive portfolio allocation (7) for the investor living in country $l$ and working in industry $s$ :

The portfolio allocation for investor $s l$ is:

$$
\mathbf{w}^{s l}=\frac{\frac{1}{\lambda}}{(1-\eta)} \underbrace{\left(\begin{array}{c}
\boldsymbol{\Omega}^{-1}(\boldsymbol{\mu}-r \mathbf{i}) \\
1-\mathbf{i}^{\prime} \boldsymbol{\Omega}^{-1}(\boldsymbol{\mu}-r \mathbf{i})
\end{array}\right)}_{\text {logarithmic portfolio }}+\frac{\left(1-\frac{1}{\lambda}\right)}{(1-\eta)} \underbrace{\left(\begin{array}{c}
\boldsymbol{\Omega}^{-1} \varpi^{l} \\
1-\mathbf{i}^{\prime} \boldsymbol{\Omega}^{-1} \varpi^{l}
\end{array}\right)}_{\pi \text { - hedging portfolio }}-\frac{\eta}{(1-\eta)} \underbrace{\left(\begin{array}{c}
\boldsymbol{\Omega}^{-1} \boldsymbol{\kappa}^{s l} \\
1-\mathbf{i}^{\prime} \boldsymbol{\Omega}^{-1} \boldsymbol{\kappa}^{s l}
\end{array}\right)}_{h-\text { hedging portfolio }}
$$


where $\mathbf{i}$ is a $N$-vector of ones, $\Omega$ is a $(N x N)$ matrix of instantaneous variances-covariances $\sigma_{j, k}$ of nominal rates of returns, $\varpi^{l}$ is a $N$-vector of covariances $\sigma_{j, \pi}^{l}$ between nominal equity return in country $j$ and country l's rate of inflation and $\boldsymbol{\kappa}^{s l}$ is a $N$-vector of covariances $\sigma_{j, h}^{s l}$ between nominal equity return $j$ and investor $s l$ 's labor income growth.

We now focusing on the first $N$ portfolios weights of the vector, representing investments in equity indexes, and ignoring the last element, the weight on the risk-free asset. Thus, we normalize to 1 the sum of stock weights, as in Baxter and Jermann (1997), since we are interested in looking at the within composition of the stock portfolio. We thus obtain the equation (7) for optimal equity portfolio composition. 


\section{Table 1. Nominal wages (Annual Rate of Growth). Descriptive statistics}

The table reports descriptive statistics (means and standard deviations) for the annual rates of growth of nominal wages for the three countries (US, Canada and Italy). Nominal wages are considered at both national and industry level (seven industries are included: Financials, Leisure, Manufacturing, Trade, Transports and Communications, Utilities, Other Services). Series are expressed in national currency. The sample period is Jan 1998: Dec 2004. Source: for US data Current Employment Statistics, for Canadian data Survey of Employment, Payrolls and Hours, for Italian data Retribuzioni e Lavoro, ISTAT.

\begin{tabular}{|c|c|c|c|c|c|c|}
\hline & \multicolumn{2}{|r|}{ USA } & \multicolumn{2}{|c|}{ Canada } & \multicolumn{2}{|c|}{ Italy } \\
\hline $\begin{array}{l}\text { Investing } \\
\text { industries }\end{array}$ & Mean & $\begin{array}{l}\text { Std. Dev. } \\
(1)\end{array}$ & Mean & $\begin{array}{l}\text { Std. Dev. } \\
\text { (2) }\end{array}$ & Mean & $\begin{array}{l}\text { Std. Dev. } \\
\text { (3) }\end{array}$ \\
\hline Trade & 0.03 & 0.02 & 0.02 & 0.01 & 0.03 & 0.02 \\
\hline Utilities & 0.03 & 0.02 & 0.02 & 0.02 & 0.02 & 0.02 \\
\hline Transport & 0.02 & 0.02 & 0.01 & 0.02 & 0.02 & 0.02 \\
\hline Other svs & 0.04 & 0.01 & 0.02 & 0.01 & 0.02 & 0.02 \\
\hline Manufact & 0.03 & 0.01 & 0.02 & 0.02 & 0.03 & 0.01 \\
\hline Financial & 0.04 & 0.01 & 0.02 & 0.01 & 0.02 & 0.01 \\
\hline Leisure & 0.03 & 0.02 & 0.01 & 0.04 & 0.02 & 0.02 \\
\hline National & 0.03 & 0.01 & 0.02 & 0.01 & 0.02 & 0.01 \\
\hline
\end{tabular}

\section{Table 2. National and Industry Nominal Wages (Annual Rate of Growth)- Correlations}

The table reports, for each country, contemporaneous correlations between national (rows) and industry (columns) specific annual rates of growth of nominal wages. We report the correlations for the overall sample period (1998-2004). Source: for US data Current Employment Statistics, for Canadian data Survey of Employment, Payrolls and Hours, for Italian data Retribuzioni e Lavoro, ISTAT.

\begin{tabular}{|ccccccc|}
\hline trade & util & transp & other & manufact & fin & leisure \\
\hline \hline 0.67 & 0.13 & -0.15 & 0.62 & -0.33 & 0.71 & 0.80 \\
\hline-0.14 & -0.42 & 0.00 & 0.73 & 0.50 & 0.38 & 0.55 \\
\hline 0.01 & 0.38 & 0.38 & 0.18 & 0.73 & 0.27 & 0.31 \\
\hline
\end{tabular}

\section{Table 3. Nominal stock returns (annual). Descriptive statistics}

The table reports descriptive statistics of annual stock indices in local currency for country based indices stock returns where ten destination countries -Canada, France, Germany, Italy, Japan, Netherlands, Sweden, United Kingdom, United States, Rest of the World - are considered. The sample period is Jan 1998: Dec 2004. Source: Datastream Stock Indices.

\begin{tabular}{|l|cc|}
\hline & & \\
Equity Market & Mean & Std.Dev. \\
\hline \hline Canada & 0.12 & 0.25 \\
France & 0.13 & 0.26 \\
Italy & 0.06 & 0.37 \\
Japan & 0.05 & 0.20 \\
Netherlands & 0.13 & 0.36 \\
Sweden & 0.07 & 0.20 \\
UK & 0.08 & 0.20 \\
US & 0.07 & 0.27 \\
Germany & 0.14 & 0.29 \\
Rest of World & 0.03 & 0.26 \\
\hline
\end{tabular}




\section{Tables 4. US optimal portfolios}

The table reports optimal equity portfolio shares invested in 10 equity indexes (by rows) by an investor living in the US and working in one of the seven industries (by columns). The last row in each portfolio represents the share invested in risk free assets. In each panel, the first seven columns report the optimal equity portfolio suitable to hedge both the national inflation risk and the industry-specific labor income risk while the eighth column reports the optimal equity portfolio suitable to hedge the national inflation risk and the national average labor income risk. The last column reports, for comparison, the market share for each destination country (i.e. the value weighted portfolio efficient in absence of background risk). Panel a) of each table reports the optimal equity portfolio composition derived considering all the estimated coefficients, while panel b) reports only significant coefficients (at 10\% confidence level).

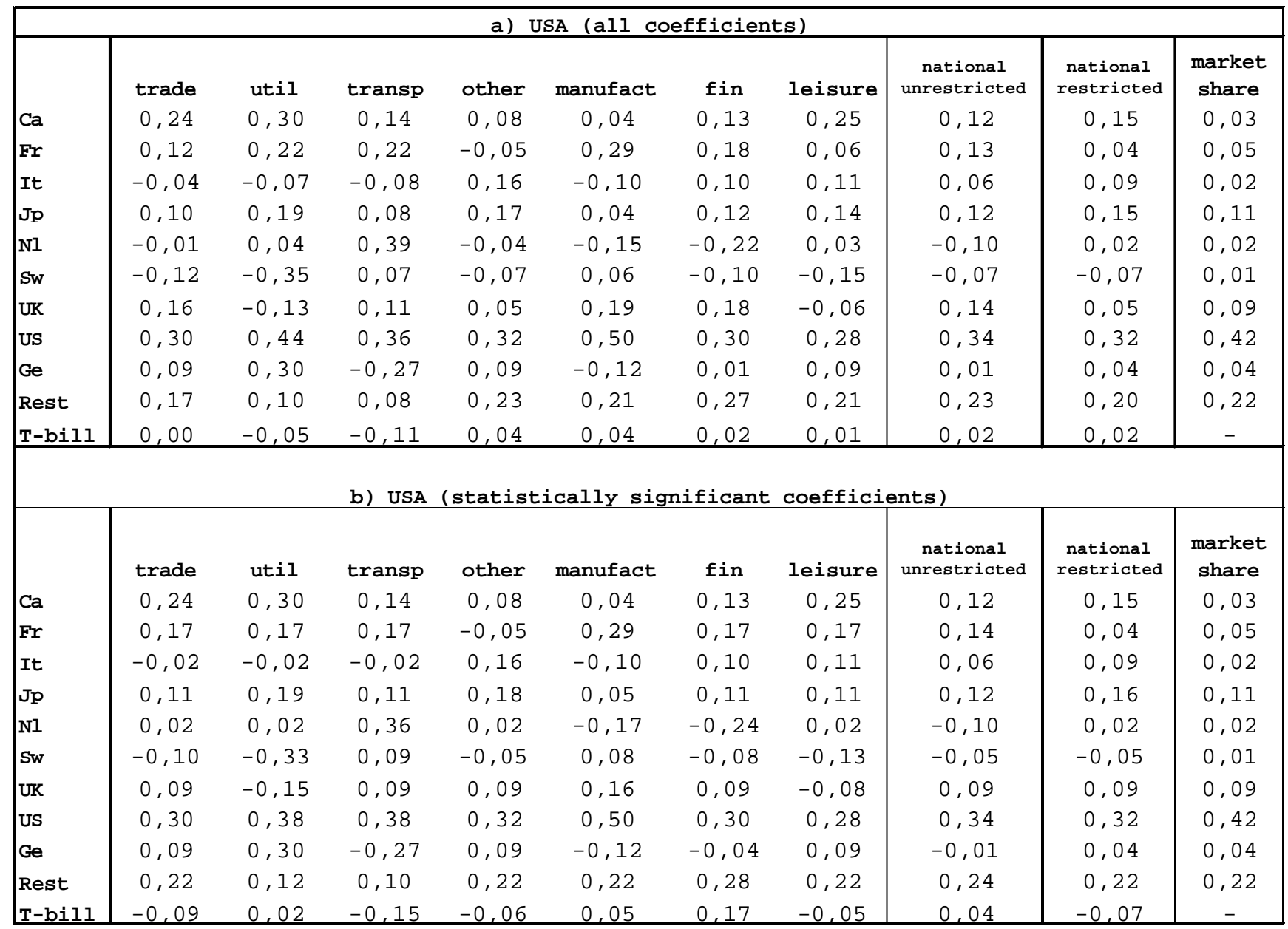




\section{Tables 5. Canada optimal portfolios}

This table reports the optimal equity portfolios shares invested in 10 equity indexes (by rows) by an investor living in Canada and working in one of the seven industries (by columns). Otherwise the table is the same as Table 4.

\begin{tabular}{|c|c|c|c|c|c|c|c|c|c|c|}
\hline \multicolumn{11}{|c|}{ a) Canada (all coefficients) } \\
\hline & trade & util & transp & other & manufact & fin & leisure & $\begin{array}{c}\text { national } \\
\text { unrestricted }\end{array}$ & $\begin{array}{l}\text { national } \\
\text { restricted }\end{array}$ & $\begin{array}{c}\text { market } \\
\text { share }\end{array}$ \\
\hline $\mathrm{Ca}$ & 0,14 & 0,24 & 0,21 & 0,07 & 0,16 & 0,00 & 0,10 & 0,10 & 0,09 & 0,03 \\
\hline Fr & $-0,08$ & $-0,10$ & 0,00 & $-0,03$ & 0,17 & $-0,11$ & $-0,62$ & $-0,04$ & $-0,02$ & 0,05 \\
\hline It & 0,15 & 0,16 & 0,20 & 0,28 & 0,06 & 0,11 & 1,06 & 0,22 & 0,19 & 0,02 \\
\hline $\mathrm{Jp}$ & 0,20 & 0,19 & 0,21 & 0,22 & 0,14 & 0,15 & 0,42 & 0,20 & 0,19 & 0,11 \\
\hline N1 & 0,10 & $-0,03$ & $-0,31$ & $-0,30$ & $-0,12$ & $-0,08$ & $-0,86$ & $-0,19$ & $-0,14$ & 0,02 \\
\hline Sw & $-0,10$ & $-0,16$ & $-0,13$ & $-0,10$ & $-0,11$ & 0,07 & $-0,29$ & $-0,09$ & $-0,08$ & 0,01 \\
\hline UK & $-0,12$ & 0,00 & 0,16 & $-0,12$ & 0,06 & 0,21 & $-0,29$ & $-0,02$ & 0,01 & 0,09 \\
\hline us & 0,30 & 0,09 & 0,27 & 0,56 & 0,37 & 0,38 & 0,45 & 0,42 & 0,39 & 0,42 \\
\hline Ge & 0,10 & 0,31 & 0,19 & 0,14 & 0,02 & 0,00 & 0,49 & 0,11 & 0,09 & 0,04 \\
\hline Rest & 0,24 & 0,24 & 0,21 & 0,24 & 0,21 & 0,18 & 0,40 & 0,23 & 0,22 & 0,22 \\
\hline T-bill & 0,07 & 0,06 & $-0,01$ & 0,05 & 0,03 & 0,09 & 0,13 & 0,06 & 0,06 & - \\
\hline \multicolumn{11}{|c|}{ ) Canada (statistically significant coefficients) } \\
\hline & trade & util & transp & other & manufact & fin & leisure & $\begin{array}{c}\text { national } \\
\text { unrestricted }\end{array}$ & $\begin{array}{c}\text { national } \\
\text { restricted }\end{array}$ & $\begin{array}{l}\text { market } \\
\text { share }\end{array}$ \\
\hline $\mathrm{Ca}$ & 0,14 & 0,24 & 0,21 & 0,10 & 0,16 & 0,00 & 0,10 & 0,11 & 0,10 & 0,03 \\
\hline Fr & 0,05 & 0,05 & 0,05 & 0,05 & 0,24 & 0,05 & $-0,54$ & 0,05 & 0,05 & 0,05 \\
\hline It & 0,18 & 0,18 & 0,18 & 0,28 & 0,06 & 0,18 & 1,06 & 0,24 & 0,18 & 0,02 \\
\hline$J p$ & 0,20 & 0,20 & 0,20 & 0,20 & 0,20 & 0,20 & 0,42 & 0,21 & 0,20 & 0,11 \\
\hline $\mathrm{Nl}$ & 0,20 & 0,02 & $-0,20$ & $-0,19$ & 0,02 & 0,02 & $-0,76$ & $-0,08$ & 0,02 & 0,02 \\
\hline Sw & $-0,09$ & $-0,09$ & $-0,09$ & $-0,09$ & $-0,09$ & 0,07 & $-0,29$ & $-0,08$ & $-0,09$ & 0,01 \\
\hline UK & $-0,04$ & 0,09 & 0,24 & $-0,04$ & 0,09 & 0,29 & 0,09 & 0,06 & 0,09 & 0,09 \\
\hline us & 0,33 & 0,09 & 0,33 & 0,56 & 0,33 & 0,33 & 0,33 & 0,41 & 0,39 & 0,42 \\
\hline Ge & 0,11 & 0,31 & 0,11 & 0,11 & 0,11 & 0,11 & 0,49 & 0,14 & 0,11 & 0,04 \\
\hline Rest & 0,22 & 0,22 & 0,22 & 0,22 & 0,22 & 0,22 & 0,40 & 0,23 & 0,22 & 0,22 \\
\hline T-bill & $-0,31$ & $-0,30$ & $-0,24$ & $-0,19$ & $-0,34$ & $-0,47$ & $-0,31$ & $-0,29$ & $-0,26$ & - \\
\hline
\end{tabular}




\section{Table 6. Italy optimal portfolios}

This table reports the optimal portfolio shares invested in 10 equity indexes (by rows) by an investor living in Italy and working in one of the seven industries (by columns). Otherwise the table is the same as Tables 4 and 5.

\begin{tabular}{|c|c|c|c|c|c|c|c|c|c|c|}
\hline \multicolumn{11}{|c|}{ a) Italy (all coefficients) } \\
\hline & trade & util & transp & other & manufact & fin & leisure & $\begin{array}{c}\text { national } \\
\text { unrestricted }\end{array}$ & $\begin{array}{c}\text { national } \\
\text { restricted }\end{array}$ & $\begin{array}{c}\text { market } \\
\text { share }\end{array}$ \\
\hline $\mathrm{Ca}$ & 0.07 & 0.22 & 0.21 & 0.04 & 0.14 & 0.03 & 0.23 & 0.09 & 0.11 & 0.03 \\
\hline $\operatorname{Fr}$ & -0.14 & 0.19 & -0.09 & 0.01 & 0.07 & 0.22 & -0.06 & 0.03 & 0.01 & 0.05 \\
\hline It & -0.04 & -0.18 & -0.04 & -0.04 & -0.04 & -0.19 & -0.02 & -0.07 & -0.01 & 0.02 \\
\hline$J p$ & 0.16 & 0.08 & 0.14 & 0.13 & 0.11 & 0.05 & 0.08 & 0.11 & 0.11 & 0.11 \\
\hline N1 & 0.02 & 0.00 & 0.00 & -0.07 & -0.14 & -0.11 & -0.06 & -0.07 & -0.14 & 0.02 \\
\hline Sw & -0.08 & -0.03 & 0.01 & -0.05 & -0.02 & 0.04 & 0.03 & -0.02 & -0.03 & 0.01 \\
\hline UK & 0.25 & 0.00 & -0.14 & 0.26 & 0.20 & 0.33 & -0.15 & 0.20 & 0.11 & 0.09 \\
\hline US & 0.54 & 0.51 & 0.46 & 0.52 & 0.47 & 0.57 & 0.47 & 0.51 & 0.50 & 0.42 \\
\hline Ge & 0.08 & 0.14 & 0.25 & 0.00 & 0.06 & -0.05 & 0.26 & 0.05 & 0.14 & 0.04 \\
\hline Rest & 0.23 & 0.05 & 0.10 & 0.23 & 0.12 & 0.13 & 0.08 & 0.17 & 0.16 & 0.22 \\
\hline T-bill & -0.09 & 0.03 & 0.12 & -0.04 & 0.03 & -0.02 & 0.16 & 0.00 & 0.04 & - \\
\hline \multicolumn{11}{|c|}{ b) Italy (statistically significant coefficients) } \\
\hline & trade & util & transp & other & manufact & fin & leisure & $\begin{array}{c}\text { national } \\
\text { unrestricted }\end{array}$ & $\begin{array}{l}\text { national } \\
\text { restricted }\end{array}$ & $\begin{array}{c}\text { market } \\
\text { share }\end{array}$ \\
\hline $\mathrm{Ca}$ & 0.03 & 0.20 & 0.20 & 0.03 & 0.12 & 0.03 & 0.21 & 0.08 & 0.09 & 0.03 \\
\hline $\operatorname{Fr}$ & 0.05 & 0.05 & 0.05 & 0.05 & 0.05 & 0.26 & 0.05 & 0.08 & 0.05 & 0.05 \\
\hline It & 0.02 & -0.17 & 0.02 & 0.02 & 0.02 & -0.18 & 0.02 & -0.01 & 0.02 & 0.02 \\
\hline $\mathrm{Jp}$ & 0.11 & 0.11 & 0.11 & 0.11 & 0.11 & 0.11 & 0.11 & 0.11 & 0.11 & 0.11 \\
\hline N1 & -0.07 & -0.07 & -0.07 & -0.07 & -0.07 & -0.07 & -0.07 & -0.07 & -0.07 & 0.02 \\
\hline Sw & 0.01 & 0.01 & 0.01 & 0.01 & 0.01 & 0.01 & 0.01 & 0.01 & 0.01 & 0.01 \\
\hline UK & 0.09 & 0.09 & -0.17 & 0.09 & 0.09 & 0.30 & -0.19 & 0.09 & 0.09 & 0.09 \\
\hline US & 0.42 & 0.42 & 0.42 & 0.51 & 0.42 & 0.56 & 0.42 & 0.47 & 0.49 & 0.42 \\
\hline $\mathrm{Ge}$ & 0.12 & 0.12 & 0.25 & 0.12 & 0.12 & -0.05 & 0.12 & 0.10 & 0.12 & 0.04 \\
\hline Rest & 0.22 & 0.06 & 0.11 & 0.22 & 0.13 & 0.14 & 0.09 & 0.17 & 0.17 & 0.22 \\
\hline T-bill & 0.00 & 0.18 & 0.08 & -0.08 & 0.00 & -0.10 & 0.22 & -0.02 & -0.07 & - \\
\hline
\end{tabular}




\section{Table 7a. Hedging components by US investing industries}

This table reports, for each US investing industry, the labor and inflation hedging components. Columns $1-7$ report the labor income hedging component at industry level. Column 8 reports the labor hedging component in the unrestricted national portfolio. Column 9 reports the inflation hedging component which is common to all industries. In the last column the total (labor plus inflation) hedging component for the national unrestricted portfolio is reported. Panel a) in each table considers portfolios where all coefficients are considered while panel b) considers portfolios where only statistically significant coefficients (at 10\% confidence level) are considered. Minimum and maximum figures are in bold face (for panel b) only values deriving from significant coefficients are considered).

\begin{tabular}{|c|c|c|c|c|c|c|c|c|c|c|}
\hline \multicolumn{11}{|c|}{ a) USA (all coefficients) } \\
\hline & \multicolumn{8}{|c|}{ Labor Hedge } & $\begin{array}{c}\text { Infl } \\
\text { Hedge }\end{array}$ & $\begin{array}{l}\text { Tot } \\
\text { Hedge }\end{array}$ \\
\hline $\mathrm{Ca}$ & 0.16 & 0.22 & 0.07 & 0.00 & -0.04 & 0.06 & 0.18 & 0.05 & 0.05 & 0.24 \\
\hline Fr & -0.04 & 0.05 & 0.05 & -0.22 & 0.12 & 0.01 & -0.10 & -0.04 & 0.12 & 0.18 \\
\hline It & -0.02 & -0.05 & -0.06 & 0.18 & -0.08 & 0.12 & 0.13 & 0.08 & -0.05 & -0.02 \\
\hline$J p$ & 0.00 & 0.08 & -0.02 & 0.07 & -0.06 & 0.02 & 0.04 & 0.02 & -0.01 & 0.02 \\
\hline $\mathrm{N} 1$ & -0.05 & 0.00 & 0.35 & -0.08 & -0.19 & -0.26 & -0.01 & -0.15 & 0.02 & -0.02 \\
\hline Sw & -0.12 & -0.34 & 0.08 & -0.06 & 0.07 & -0.09 & -0.14 & -0.06 & -0.02 & -0.18 \\
\hline UK & 0.05 & -0.24 & 0.00 & -0.06 & 0.08 & 0.07 & -0.17 & 0.03 & 0.02 & -0.02 \\
\hline US & -0.09 & 0.06 & -0.02 & -0.06 & 0.12 & -0.08 & -0.10 & -0.04 & -0.04 & -0.11 \\
\hline Ge & 0.13 & 0.34 & -0.23 & 0.13 & -0.08 & 0.05 & 0.13 & 0.05 & -0.08 & -0.01 \\
\hline Rest & -0.02 & -0.10 & -0.12 & 0.03 & 0.01 & 0.07 & 0.02 & 0.03 & -0.02 & -0.06 \\
\hline \multicolumn{11}{|c|}{ b) USA (statistically significant coefficients) } \\
\hline & \multicolumn{8}{|c|}{ Labor Hedge } & $\begin{array}{c}\text { Infl } \\
\text { Hedge }\end{array}$ & $\begin{array}{c}\text { Tot } \\
\text { Hedge }\end{array}$ \\
\hline $\mathrm{Ca}$ & 0.16 & 0.22 & 0.07 & - & -0.04 & 0.06 & 0.18 & 0.05 & 0.05 & 0.09 \\
\hline Fr & - & - & - & -0.22 & 0.12 & - & - & -0.03 & 0.12 & 0.09 \\
\hline It & - & - & - & 0.18 & -0.08 & 0.12 & 0.13 & 0.08 & -0.05 & 0.04 \\
\hline$J p$ & - & 0.08 & - & 0.07 & -0.06 & - & - & 0.01 & - & 0.01 \\
\hline $\mathrm{Nl}$ & - & - & 0.35 & - & -0.19 & -0.26 & - & -0.12 & - & -0.12 \\
\hline Sw & -0.12 & -0.34 & 0.08 & -0.06 & 0.07 & -0.09 & -0.14 & -0.06 & - & -0.06 \\
\hline UK & - & -0.24 & - & - & 0.08 & - & -0.17 & 0.01 & - & 0.01 \\
\hline us & -0.09 & - & - & -0.06 & 0.12 & -0.08 & -0.10 & -0.04 & -0.04 & -0.08 \\
\hline Ge & 0.13 & 0.34 & -0.23 & 0.13 & -0.08 & - & 0.13 & 0.03 & -0.08 & -0.04 \\
\hline Rest & _ & -0.10 & -0.12 & _ & - & 0.07 & - & 0.02 & - & 0.02 \\
\hline
\end{tabular}




\section{Table 7b. Relative hedging components by US investing industries}

This table reports, for each US investing industry, the relative weight of the labor and inflation hedging component: it contains the same figures as in table 7 a scaled by the market share of the destination country. Panel a) in each table considers portfolios where all coefficients are considered while panel b) considers portfolios where only statistically significant coefficients (at 10\% confidence level) are considered. Minimum and maximum ratios are in bold face (for panel b) only ratios corresponding to significant coefficients are considered).

\begin{tabular}{|c|c|c|c|c|c|c|c|c|c|c|}
\hline \multicolumn{11}{|c|}{ a) USA (all coefficients) } \\
\hline \multirow[b]{2}{*}{$\mathrm{Ca}$} & \multicolumn{7}{|c|}{ (Labor Hedge) /MS } & nat. unrestr. & $\begin{array}{c}\text { Infl Hedge } \\
\text { MS }\end{array}$ & $\begin{array}{c}\text { Tot Hedge } \\
\text { MS }\end{array}$ \\
\hline & 5.36 & 7.36 & 2.25 & 0.05 & -1.28 & 1.97 & 5.90 & 1.58 & 1.53 & 7.87 \\
\hline Fr & -0.97 & 1.18 & 1.13 & -4.81 & 2.73 & 0.15 & -2.29 & -0.82 & 2.72 & 3.93 \\
\hline It & -0.89 & -2.01 & -2.52 & 7.46 & -3.11 & 4.95 & 5.44 & 3.19 & -1.89 & -0.95 \\
\hline$J p$ & -0.03 & 0.78 & -0.18 & 0.64 & -0.56 & 0.17 & 0.36 & 0.14 & -0.05 & 0.21 \\
\hline N1 & -2.67 & -0.20 & 17.80 & -4.35 & -9.87 & -13.51 & -0.52 & -7.65 & 1.26 & -1.09 \\
\hline Sw & -10.62 & -30.91 & 7.18 & -5.58 & 6.14 & -8.01 & -12.52 & -5.24 & -1.76 & -16.26 \\
\hline UK & 0.55 & -2.73 & 0.04 & -0.67 & 0.90 & 0.84 & -1.93 & 0.31 & 0.28 & -0.26 \\
\hline us & -0.21 & 0.15 & -0.06 & -0.14 & 0.28 & -0.18 & -0.24 & -0.09 & -0.10 & -0.26 \\
\hline Ge & 3.57 & 9.72 & -6.43 & 3.78 & $-2 \cdot 30$ & 1.31 & 3.80 & 1.48 & -2.15 & -0.39 \\
\hline Rest & -0.10 & -0.47 & -0.54 & 0.16 & 0.05 & 0.32 & 0.08 & 0.14 & -0.09 & -0.27 \\
\hline \multicolumn{11}{|c|}{ b) USA (statistically significant coefficients) } \\
\hline & \multicolumn{8}{|c|}{ (Labor Hedge) /MS } & $\begin{array}{c}\text { Infl_ Hedge } \\
\text { MS }\end{array}$ & $\begin{array}{c}\text { Tot Hedge } \\
\text { MS }\end{array}$ \\
\hline $\mathrm{Ca}$ & 5.36 & 7.36 & 2.25 & - & -1.28 & 1.97 & 5.90 & 1.57 & 1.53 & 3.10 \\
\hline Fr & - & - & - & -4.81 & 2.73 & - & - & -0.73 & 2.72 & 1.98 \\
\hline It & - & - & - & 7.46 & -3.11 & 4.95 & 5.44 & 3.42 & -1.89 & 1.53 \\
\hline$J p$ & - & 0.78 & - & 0.64 & -0.56 & - & - & 0.07 & - & 0.07 \\
\hline Nl & - & - & 17.80 & - & -9.87 & -13.51 & - & -6.23 & - & -6.23 \\
\hline Sw & -10.62 & -30.91 & 7.18 & -5.58 & 6.14 & -8.01 & -12.52 & -5.24 & - & -5.24 \\
\hline UK & - & -2.73 & - & - & 0.90 & - & -1.93 & 0.07 & - & 0.07 \\
\hline US & -0.21 & - & - & -0.14 & 0.28 & -0.18 & -0.24 & -0.09 & -0.10 & -0.19 \\
\hline Ge & 3.57 & 9.72 & -6.43 & 3.78 & $-2 \cdot 30$ & - & 3.80 & 0.97 & -2.15 & -1.18 \\
\hline Rest & - & -0.47 & -0.54 & - & - & 0.32 & - & 0.10 & - & 0.10 \\
\hline
\end{tabular}


Table 8a. Hedging components by Canadian investing industries

Table 8a reports, for each Canadian investing industry, the labor and inflation hedging component. Otherwise the table is the same as Table $7 \mathrm{a}$.

\begin{tabular}{|c|c|c|c|c|c|c|c|c|c|c|}
\hline \multicolumn{11}{|c|}{ a) Canada (all coefficients) } \\
\hline & \multicolumn{8}{|c|}{ Labor Hedge } & Infl Hedge & $\begin{array}{l}\text { Tot } \\
\text { Hedge }\end{array}$ \\
\hline $\mathrm{Ca}$ & 0.04 & 0.14 & 0.11 & -0.04 & 0.06 & -0.10 & 0.00 & 0.00 & 0.07 & 0.07 \\
\hline Fr & -0.06 & -0.08 & 0.02 & -0.01 & 0.20 & -0.08 & -0.59 & -0.01 & -0.07 & -0.09 \\
\hline It & -0.03 & -0.02 & 0.01 & 0.10 & -0.12 & -0.07 & 0.87 & 0.04 & 0.16 & 0.20 \\
\hline$J p$ & 0.00 & 0.00 & 0.02 & 0.02 & -0.05 & -0.05 & 0.23 & 0.00 & 0.09 & 0.09 \\
\hline N1 & 0.19 & 0.05 & -0.22 & -0.21 & -0.03 & 0.00 & -0.78 & -0.10 & -0.10 & -0.21 \\
\hline Sw & -0.02 & -0.07 & -0.04 & -0.01 & -0.02 & 0.16 & -0.20 & 0.00 & -0.10 & -0.10 \\
\hline UK & -0.13 & 0.00 & 0.15 & -0.12 & 0.05 & 0.20 & -0.30 & -0.03 & -0.08 & -0.11 \\
\hline us & -0.03 & -0.24 & -0.06 & 0.22 & 0.04 & 0.05 & 0.12 & 0.09 & -0.09 & 0.00 \\
\hline Ge & -0.01 & 0.20 & 0.08 & 0.02 & -0.09 & -0.12 & 0.38 & 0.00 & 0.08 & 0.08 \\
\hline Rest & 0.03 & 0.02 & 0.00 & 0.02 & 0.00 & -0.03 & 0.19 & 0.02 & 0.00 & 0.01 \\
\hline \multicolumn{11}{|c|}{ b) Canada (statistically significant coefficients) } \\
\hline & \multicolumn{8}{|c|}{ Labor Hedge } & \multirow{2}{*}{ Infl Hedge } & \multirow{2}{*}{$\begin{array}{l}\text { Tot } \\
\text { Hedge }\end{array}$} \\
\hline & trade & util & transp & other & manufact & fin & leisure & nat. unrestr. & & \\
\hline $\mathrm{Ca}$ & 0.04 & 0.14 & 0.11 & - & 0.06 & -0.10 & - & 0.01 & 0.07 & 0.08 \\
\hline Fr & - & - & - & - & 0.20 & - & -0.59 & 0.01 & - & 0.01 \\
\hline It & - & - & - & 0.10 & -0.12 & - & 0.87 & 0.06 & 0.16 & 0.21 \\
\hline$J p$ & - & - & - & - & - & - & 0.23 & 0.01 & 0.09 & 0.10 \\
\hline N1 & 0.19 & - & -0.22 & -0.21 & - & - & -0.78 & -0.10 & - & -0.10 \\
\hline Sw & - & - & - & - & - & 0.16 & -0.20 & 0.01 & -0.10 & -0.09 \\
\hline UK & -0.13 & - & 0.15 & -0.12 & - & 0.20 & - & -0.02 & 0.00 & -0.02 \\
\hline us & - & -0.24 & - & 0.22 & - & - & - & 0.07 & -0.09 & -0.02 \\
\hline Ge & - & 0.20 & - & - & - & - & 0.38 & 0.02 & 0.08 & 0.10 \\
\hline Rest & - & - & - & - & - & - & 0.19 & 0.01 & - & 0.01 \\
\hline
\end{tabular}


Table 8b. Relative hedging components by Canadian investing industries

Table 8 b reports, for each Canadian investing industry, the relative weight of the labor and inflation hedging component: it contains the same figures as in table 8 a but scaled by the market share of the destination country. Otherwise the table is the same as Table $7 \mathrm{~b}$.

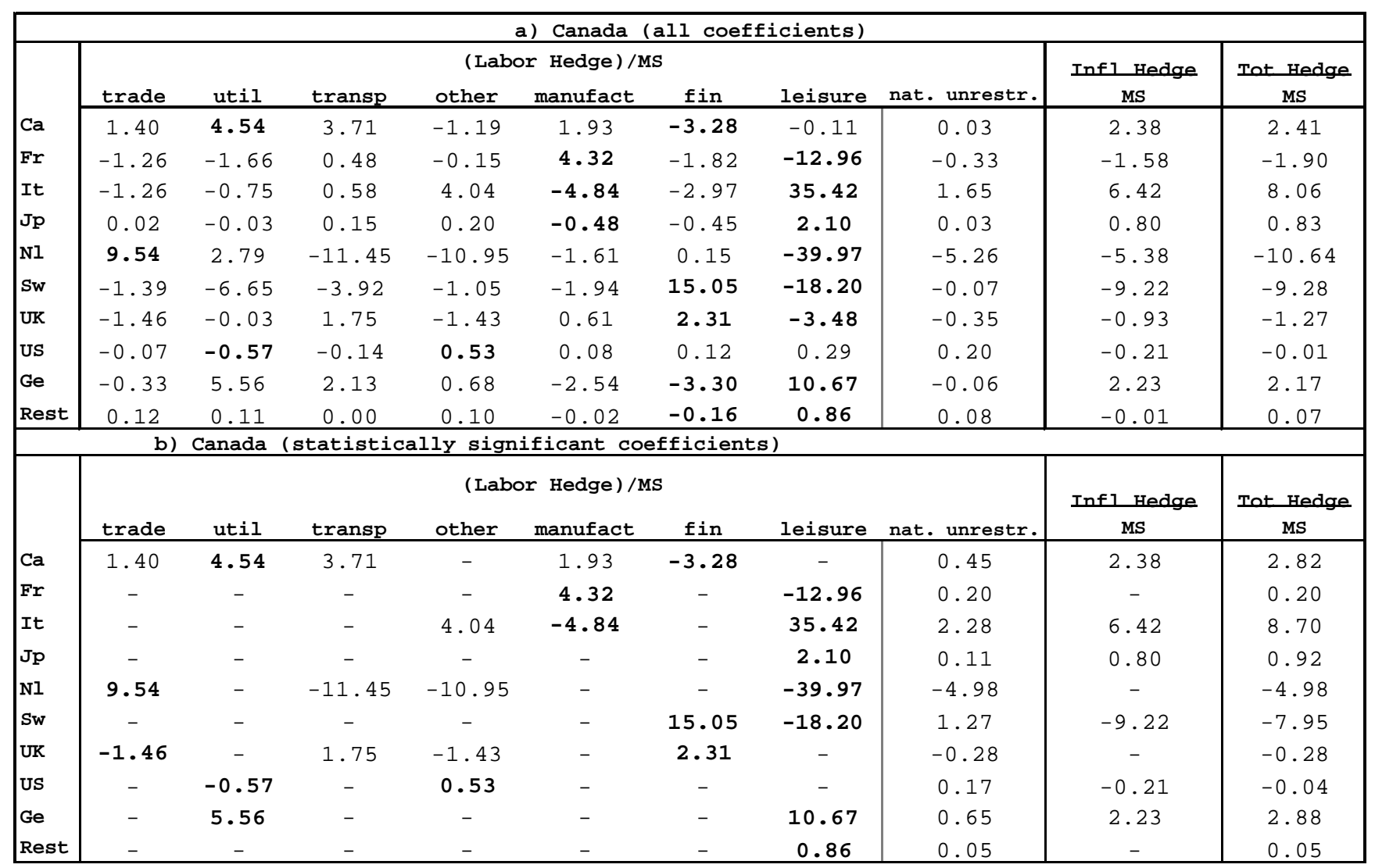


Table 9a. Hedging components by Italian investing industries

Table 9a reports, for each Italian investing industry, the labor and inflation hedging component. Otherwise the table is the same as Tables $7 \mathrm{a}$ and $8 \mathrm{a}$.

\begin{tabular}{|c|c|c|c|c|c|c|c|c|c|c|}
\hline \multicolumn{11}{|c|}{ a) Italy (all coefficients) } \\
\hline \multirow[b]{2}{*}{$\mathrm{Ca}$} & \multicolumn{8}{|c|}{ Labor Hedge } & Infl Hedge & $\begin{array}{l}\text { Tot } \\
\text { Hedge }\end{array}$ \\
\hline & 0.03 & 0.17 & 0.17 & 0.00 & 0.09 & -0.02 & 0.18 & 0.05 & 0.02 & 0.06 \\
\hline Fr & -0.14 & 0.19 & -0.10 & 0.01 & 0.07 & 0.21 & -0.06 & 0.03 & -0.04 & -0.02 \\
\hline It & -0.05 & -0.19 & -0.05 & -0.05 & -0.06 & -0.20 & -0.04 & -0.08 & -0.01 & -0.09 \\
\hline$J p$ & 0.06 & -0.01 & 0.04 & 0.03 & 0.02 & -0.05 & -0.01 & 0.02 & -0.01 & 0.00 \\
\hline $\mathrm{N} 1$ & 0.09 & 0.07 & 0.07 & 0.01 & -0.07 & -0.04 & 0.01 & 0.00 & -0.09 & -0.09 \\
\hline Sw & -0.08 & -0.04 & 0.01 & -0.05 & -0.02 & 0.04 & 0.03 & -0.02 & -0.01 & -0.03 \\
\hline UK & 0.13 & -0.12 & -0.26 & 0.14 & 0.08 & 0.21 & -0.27 & 0.08 & 0.03 & 0.12 \\
\hline us & 0.10 & 0.07 & 0.02 & 0.08 & 0.03 & 0.13 & 0.03 & 0.07 & 0.02 & 0.09 \\
\hline Ge & -0.05 & 0.02 & 0.13 & -0.13 & -0.06 & -0.18 & 0.13 & -0.07 & 0.09 & 0.01 \\
\hline Rest & 0.02 & -0.16 & -0.11 & 0.02 & -0.08 & -0.08 & -0.13 & -0.04 & -0.01 & -0.05 \\
\hline \multicolumn{11}{|c|}{ b) Italy (statistically significant coefficients) } \\
\hline & \multicolumn{8}{|c|}{ Labor Hedge } & \multirow{2}{*}{ Infl Hedge } & \multirow{2}{*}{$\begin{array}{c}\text { Tot } \\
\text { Hedge }\end{array}$} \\
\hline & trade & util & transp & other & manufact & fin & leisure & nat. unrestr. & & \\
\hline $\mathrm{Ca}$ & - & 0.17 & 0.17 & - & 0.09 & - & 0.18 & 0.05 & - & 0.05 \\
\hline Fr & - & - & - & - & - & 0.21 & - & 0.04 & - & 0.04 \\
\hline It & - & -0.19 & - & - & - & -0.20 & - & -0.04 & - & -0.04 \\
\hline$J p$ & - & - & - & - & - & - & - & - & - & - \\
\hline N1 & - & - & - & - & - & - & - & - & -0.09 & -0.09 \\
\hline Sw & - & - & - & - & - & - & - & - & - & - \\
\hline UK & - & - & -0.26 & - & - & 0.21 & -0.27 & - & - & - \\
\hline us & - & - & - & 0.08 & - & 0.13 & - & 0.05 & - & 0.05 \\
\hline Ge & - & - & 0.13 & - & - & -0.18 & - & -0.02 & 0.09 & 0.07 \\
\hline Rest & - & -0.16 & -0.11 & - & -0.08 & -0.08 & -0.13 & -0.05 & - & -0.05 \\
\hline
\end{tabular}


Table 9b. Relative hedging components by Italian investing industries

Table $9 \mathrm{~b}$ reports, for each Italian investing industry, the relative weight of the labor and inflation hedging component: it contains the same figures as in table 9 a but scaled by the market share of the destination country. Otherwise the table is the same as Table $7 \mathrm{~b}$ and $8 \mathrm{~b}$.

\begin{tabular}{|c|c|c|c|c|c|c|c|c|c|c|}
\hline \multicolumn{11}{|c|}{ a) Italy (all coefficients) } \\
\hline & \multicolumn{8}{|c|}{ (Labor Hedge)/MS } & $\begin{array}{c}\text { Infl_Hedge } \\
\text { MS }\end{array}$ & $\begin{array}{c}\text { Tot Hedge } \\
\text { MS }\end{array}$ \\
\hline $\mathrm{Ca}$ & 0.84 & 5.66 & 5.50 & -0.11 & 2.99 & -0.54 & 6.05 & 1.51 & 0.60 & 2.11 \\
\hline Fr & -3.03 & 4.12 & -2.12 & 0.19 & 1.53 & 4.72 & -1.34 & 0.61 & -0.97 & -0.36 \\
\hline It & -2.06 & -7.87 & -2.14 & -2.11 & -2.26 & -8.29 & -1.50 & -3.24 & -0.49 & -3.73 \\
\hline$J p$ & 0.57 & -0.13 & 0.37 & 0.31 & 0.17 & -0.46 & -0.11 & 0.16 & -0.13 & 0.03 \\
\hline N1 & 4.70 & 3.70 & 3.52 & 0.29 & -3.42 & -2.03 & 0.41 & -0.08 & -4.73 & -4.81 \\
\hline Sw & -7.64 & -3.34 & 0.48 & -4.47 & -2.18 & 3.79 & 2.66 & -2.24 & -0.75 & -2.99 \\
\hline UK & 1.52 & -1.40 & -3.00 & 1.62 & 0.94 & 2.48 & -3.16 & 0.98 & 0.37 & 1.35 \\
\hline us & 0.24 & 0.17 & 0.04 & 0.20 & 0.06 & 0.32 & 0.06 & 0.17 & 0.04 & 0.21 \\
\hline Ge & -1.32 & 0.46 & 3.59 & -3.60 & -1.82 & -4.94 & 3.73 & -2.11 & 2.49 & 0.39 \\
\hline \multirow[t]{3}{*}{ Rest } & 0.10 & -0.72 & -0.50 & 0.11 & -0.39 & -0.35 & -0.59 & -0.18 & -0.04 & -0.23 \\
\hline & \multicolumn{10}{|c|}{ b) Italy (statistically significant coefficients) } \\
\hline & \multicolumn{8}{|c|}{ (Labor Hedge) /MS } & $\begin{array}{c}\text { Infl_Hedge } \\
\text { MS }\end{array}$ & $\begin{array}{c}\text { Tot Hedge } \\
\text { MS }\end{array}$ \\
\hline $\mathrm{Ca}$ & - & 5.66 & 5.50 & - & 2.99 & - & 6.05 & 1.51 & - & 1.51 \\
\hline Fr & - & - & - & - & - & 4.72 & - & 0.81 & - & 0.81 \\
\hline It & - & -7.87 & - & - & - & -8.29 & - & -1.51 & - & -1.51 \\
\hline$J p$ & - & - & - & - & - & - & - & - & - & - \\
\hline N1 & - & - & - & - & - & - & - & - & -4.73 & -4.73 \\
\hline Sw & - & - & - & - & - & - & - & - & - & - \\
\hline UK & - & - & -3.00 & - & - & 2.48 & -3.16 & 0.05 & - & 0.05 \\
\hline US & - & - & - & 0.20 & - & 0.32 & - & 0.11 & - & 0.11 \\
\hline $\mathrm{Ge}$ & - & - & 3.59 & - & - & -4.94 & - & -0.59 & 2.49 & 1.90 \\
\hline Rest & - & -0.72 & -0.50 & - & -0.39 & -0.35 & -0.59 & -0.23 & - & -0.23 \\
\hline
\end{tabular}




\section{Table 10. Size of hedging components: industry vs national restricted}

The table reports, for each country, the size of hedging components, i.e. the hedging components in absolute value. Panel a) refers to US investing country, panel b) and c) to Canada and Italy, respectively. In columns (1) and (2) we report the size of inflation hedging component common to all industries. In (3) and (4) we report the weighted average of the size of the labor hedging components across all industries. Columns (5) and (6) report the size of the labor hedging component in the national restricted portfolio. In the last column of the table we report, for comparison, the market share of each destination country. The last row in each panel reports the sum of the absolute hedging components across all destination countries. Results are derived for portfolios with all coefficients $((1),(3),(5))$ and for those with only significant coefficients ((2), (4), (6)).

\begin{tabular}{|c|c|c|c|c|c|c|c|}
\hline \multicolumn{8}{|c|}{ a) USA } \\
\hline & \multicolumn{2}{|c|}{ Infl Hedge } & \multicolumn{2}{|c|}{$\begin{array}{l}\text { Abs Labor Hedge } \\
\text { industry wgt av }\end{array}$} & \multicolumn{2}{|c|}{$\begin{array}{l}\text { Abs Labor Hedge } \\
\text { national restr. }\end{array}$} & \multirow[b]{2}{*}{$\begin{array}{c}\text { market } \\
\text { share }\end{array}$} \\
\hline & $\begin{array}{c}\text { all } \\
\text { coeffs }\end{array}$ & $\begin{array}{c}\text { sign. } \\
\text { coeffs }\end{array}$ & $\begin{array}{c}\text { all } \\
\text { coeffs }\end{array}$ & $\begin{array}{l}\text { sign. } \\
\text { coeffs }\end{array}$ & $\begin{array}{c}\text { all } \\
\text { coeffs }\end{array}$ & $\begin{array}{l}\text { sign. } \\
\text { coeffs }\end{array}$ & \\
\hline & (1) & (2) & (3) & (4) & (5) & (6) & \\
\hline $\mathrm{Ca}$ & 0.05 & 0.05 & 0.06 & 0.06 & 0.08 & 0.08 & 0.03 \\
\hline $\mathbf{F r}$ & 0.12 & 0.12 & 0.09 & 0.07 & 0.13 & 0.13 & 0.05 \\
\hline It & 0.05 & 0.05 & 0.11 & 0.11 & 0.11 & 0.11 & 0.02 \\
\hline$J_{p}$ & 0.01 & - & 0.04 & 0.03 & 0.05 & 0.05 & 0.11 \\
\hline N1 & 0.02 & - & 0.17 & 0.15 & 0.03 & - & 0.02 \\
\hline Sw & 0.02 & - & 0.08 & 0.08 & 0.06 & 0.06 & 0.01 \\
\hline UK & 0.02 & - & 0.07 & 0.02 & 0.06 & - & 0.09 \\
\hline US & 0.04 & 0.04 & 0.08 & 0.08 & 0.07 & 0.07 & 0.42 \\
\hline Ge & 0.08 & 0.08 & 0.10 & 0.08 & 0.09 & 0.09 & 0.04 \\
\hline Rest & 0.02 & - & 0.05 & 0.03 & 0.00 & - & 0.22 \\
\hline sum hedge & 0.42 & 0.33 & 0.84 & 0.71 & 0.67 & 0.58 & \\
\hline \multicolumn{8}{|c|}{ b) Canada } \\
\hline $\mathrm{Ca}$ & 0.07 & 0.07 & 0.06 & 0.04 & 0.01 & - & 0.03 \\
\hline $\mathbf{F r}$ & 0.07 & - & 0.10 & 0.07 & 0.01 & - & 0.05 \\
\hline It & 0.16 & 0.16 & 0.12 & 0.11 & 0.00 & - & 0.02 \\
\hline$J p$ & 0.09 & 0.09 & 0.04 & 0.01 & 0.01 & - & 0.11 \\
\hline N1 & 0.10 & - & 0.17 & 0.16 & 0.05 & - & 0.02 \\
\hline Sw & 0.10 & 0.10 & 0.05 & 0.04 & 0.01 & - & 0.01 \\
\hline UK & 0.08 & - & 0.13 & 0.10 & 0.00 & - & 0.09 \\
\hline US & 0.09 & 0.09 & 0.11 & 0.08 & 0.06 & 0.06 & 0.42 \\
\hline $\mathrm{Ge}$ & 0.08 & 0.08 & 0.07 & 0.02 & 0.03 & - & 0.04 \\
\hline Rest & 0.00 & - & 0.03 & 0.01 & 0.00 & - & 0.22 \\
\hline sum hedge & 0.85 & 0.59 & 0.88 & 0.64 & 0.19 & 0.06 & \\
\hline \multicolumn{8}{|c|}{ c) Italy } \\
\hline $\mathrm{Ca}$ & 0.02 & - & 0.05 & 0.05 & 0.03 & 0.06 & 0.03 \\
\hline$F r$ & 0.04 & - & 0.09 & 0.04 & 0.14 & - & 0.05 \\
\hline It & 0.01 & - & 0.08 & 0.04 & 0.05 & - & 0.02 \\
\hline$J p$ & 0.01 & - & 0.04 & - & 0.06 & - & 0.11 \\
\hline N1 & 0.09 & 0.09 & 0.04 & - & 0.09 & - & 0.02 \\
\hline Sw & 0.01 & - & 0.04 & - & 0.08 & - & 0.01 \\
\hline UK & 0.03 & - & 0.15 & 0.07 & 0.13 & - & 0.09 \\
\hline US & 0.02 & - & 0.07 & 0.05 & 0.10 & 0.06 & 0.42 \\
\hline $\mathrm{Ge}$ & 0.09 & 0.09 & 0.11 & 0.04 & 0.05 & - & 0.04 \\
\hline Rest & 0.01 & - & 0.06 & 0.05 & 0.02 & 0.05 & 0.22 \\
\hline sum hedge & 0.33 & 0.18 & 0.74 & 0.32 & 0.75 & 0.17 & \\
\hline
\end{tabular}




\section{Table 11. Absolute distance industry-national}

This table reports for each optimal portfolio weight at industry level the absolute distance from the optimal corresponding weight at national level. Here only significant differences are considered (Wald test at $10 \%$ confidence level). The optimal portfolio hedging the national labor income risk (national restricted ptf) is reported in the last column, while columns from 1 to 7 show the distance of each optimal industry portfolio weight from the corresponding weight in the national restricted ptf. Panel a) refers to US investing industries, panel b) and c) to Canadian and Italian industries, respectively.

\begin{tabular}{|c|c|c|c|c|c|c|c|c|}
\hline \multicolumn{9}{|c|}{ a) USA } \\
\hline & trade & util & transp & other & manufact & fin & leisure & $\begin{array}{l}\text { national } \\
\text { restricted }\end{array}$ \\
\hline $\mathrm{Ca}$ & 0.08 & - & - & 0.07 & 0.11 & - & 0.10 & 0.15 \\
\hline $\operatorname{Fr}$ & 0.09 & 0.19 & 0.18 & 0.09 & 0.26 & 0.14 & - & 0.04 \\
\hline It & 0.13 & - & 0.17 & 0.07 & 0.19 & - & - & 0.09 \\
\hline$J p$ & 0.05 & 0.03 & - & - & 0.11 & - & - & 0.15 \\
\hline N1 & - & - & 0.37 & - & - & 0.23 & - & 0.02 \\
\hline Sw & 0.06 & - & 0.14 & - & 0.13 & - & 0.08 & -0.07 \\
\hline UK & 0.11 & 0.18 & - & - & 0.14 & 0.13 & 0.11 & 0.05 \\
\hline US & - & - & - & - & 0.18 & - & - & 0.32 \\
\hline Ge & - & 0.26 & 0.31 & 0.05 & 0.17 & - & - & 0.04 \\
\hline Rest & - & 0.10 & 0.12 & 0.04 & - & 0.07 & - & 0.20 \\
\hline \multicolumn{9}{|c|}{ b) Canada } \\
\hline & trade & util & transp & other & manufact & fin & leisure & $\begin{array}{l}\text { national } \\
\text { restricted }\end{array}$ \\
\hline $\mathrm{Ca}$ & 0.05 & 0.15 & 0.12 & - & 0.07 & 0.09 & - & 0.09 \\
\hline Fr & - & - & - & - & 0.19 & - & 0.60 & -0.02 \\
\hline It & - & - & - & 0.10 & 0.12 & - & 0.87 & 0.19 \\
\hline $\mathrm{Jp}$ & - & - & - & 0.03 & - & - & 0.24 & 0.19 \\
\hline N1 & 0.24 & - & - & 0.16 & - & - & 0.72 & -0.14 \\
\hline Sw & - & - & - & - & - & 0.15 & 0.21 & -0.08 \\
\hline UK & 0.13 & - & 0.15 & 0.13 & - & 0.20 & - & 0.01 \\
\hline US & 0.09 & 0.30 & 0.12 & 0.17 & - & - & - & 0.39 \\
\hline Ge & - & 0.23 & - & - & - & - & 0.41 & 0.09 \\
\hline Rest & - & - & - & - & - & - & 0.18 & 0.06 \\
\hline \multicolumn{9}{|c|}{ c) Italy } \\
\hline & trade & util & transp & other & manufact & fin & leisure & $\begin{array}{l}\text { national } \\
\text { restricted }\end{array}$ \\
\hline $\mathrm{Ca}$ & - & 0.11 & 0.10 & - & 0.03 & 0.08 & 0.12 & 0.11 \\
\hline Fr & - & - & - & - & - & 0.20 & - & 0.01 \\
\hline It & - & 0.17 & - & - & - & 0.18 & - & -0.01 \\
\hline $\mathrm{Jp}$ & - & - & - & - & - & 0.07 & - & 0.11 \\
\hline N1 & - & - & - & - & - & - & - & -0.14 \\
\hline Sw & - & - & - & - & - & 0.07 & - & -0.03 \\
\hline UK & - & - & 0.25 & - & 0.09 & 0.23 & 0.26 & 0.11 \\
\hline US & - & - & - & - & - & 0.07 & - & 0.50 \\
\hline Ge & - & - & 0.11 & - & 0.08 & 0.19 & - & 0.14 \\
\hline Rest & - & 0.11 & 0.06 & - & 0.04 & - & 0.08 & 0.04 \\
\hline
\end{tabular}




\section{Table 12. Synthetic measures of dispersion (fully hedged)}

Table 12.I and 12.II report synthetic measures of dispersion of optimal equity portfolios across investing industries for fully hedged and unhedged positions, respectively. The measures of dispersion are computed around the national restricted portfolio. Reported measures are derived, alternatively, on all distances ((1), (3), (5)) and on only significant distances ((2), (4), (6)). Panel a) reports the standard deviation of industry portfolios (around the national portfolio) while panel b) reports the standard deviation of individual weights in industry portfolios (around individual weights in the national portfolio). Both unweighted and weighted measures are considered (in the weighted measure the weights are computed considering the labor compensation of each investing industry on total labor compensation in each country). The unweighted standard deviation of the $\mathrm{S}$ industry portfolios in country $l$ with respect to the restricted national portfolio $l$ is computed as

$\sigma_{P U}^{\prime}=\sqrt{\frac{\sum_{s=1}^{S} \sum_{j=1}^{N+1}\left(W_{j}^{s l}-\overline{W^{l}} j\right)^{2}}{S}}$

where $S$ is the total number (seven) of industries in country $l, N+1$ is the total number of destination equity indices (ten) plus the risk-free asset, $\mathbf{W}_{\mathrm{j}}{ }^{\mathrm{Sl}}$ is the optimal weight of equity index $j$ in the portfolio of industry $s$ in country $l, \mathbf{W}_{\mathrm{j}}^{\top}$ is the optimal weight of equity index $j$ in the restricted national portfolio of country $l$. The weighted standard deviation of the $\mathrm{S}$ industry portfolios in country $l$ with respect to the restricted national portfolio $l$ is computed as

$\sigma^{\prime}{ }_{P W}=\sqrt{\sum_{S=1}^{S} \sum_{j=1}^{N+1} V^{S l}\left(W_{j}{ }^{S l}-\overline{W^{l}} j\right)^{2}}$

where $v$ sl here is the relative weight of industry $s$ in country $l$, measured by the total labor income compensation paid in industry $s$ relative to the total labor income compensation in country $l$.

The unweighted and weighted standard deviations of the $\mathrm{S}$ industry portfolio weights in country $l$ with respect to the weights in restricted national portfolio $l$ are computed, respectively, as

$\sigma^{\prime}{ }_{w U}=\sqrt{\frac{\left(\sigma_{\text {PU }}\right)^{2}}{N+1}}$ and $\sigma^{\prime}{ }_{w w}=\sqrt{\frac{\left(\sigma_{\text {PW }}\right)^{2}}{N+1}}$

\section{Fully hedged}

\begin{tabular}{|l|cc|cc|cc|}
\hline \multirow{7}{*}{} & United States & \multicolumn{2}{c|}{ Canada } & \multicolumn{2}{c|}{ Italy } \\
\cline { 2 - 8 } & $\begin{array}{c}\text { all } \\
\text { dist. } \\
\text { (1) }\end{array}$ & $\begin{array}{c}\text { sign. } \\
\text { dist. } \\
\text { (2) }\end{array}$ & $\begin{array}{c}\text { all } \\
\text { dist. } \\
\text { (3) }\end{array}$ & $\begin{array}{c}\text { sign. } \\
\text { dist. } \\
\text { (4) }\end{array}$ & $\begin{array}{c}\text { all } \\
\text { dist. } \\
\text { (5) }\end{array}$ & $\begin{array}{c}\text { sign. } \\
\text { dist. } \\
\text { (6) }\end{array}$ \\
\hline weighted & 0,33 & 0,32 & 0,44 & 0,42 & 0,30 & 0,22 \\
unweighted & 0,40 & 0,36 & 0,62 & 0,56 & 0,33 & 0,25 \\
\hline \multicolumn{8}{|c|}{ b) } & weights \\
\hline weighted & 0,10 & 0,10 & 0,13 & 0,13 & 0,09 & 0,07 \\
unweighted & 0,12 & 0,11 & 0,19 & 0,19 & 0,10 & 0,08 \\
\hline
\end{tabular}

II. Unhedged

\begin{tabular}{|l|cc|cc|cc|}
\hline & United States & Canada & \multicolumn{2}{c|}{ Italy } \\
\cline { 2 - 8 } & $\begin{array}{c}\text { all } \\
\text { dist. } \\
\text { (1) }\end{array}$ & $\begin{array}{c}\text { sign. } \\
\text { dist. } \\
\text { (2) }\end{array}$ & $\begin{array}{c}\text { all } \\
\text { dist. } \\
\text { (3) }\end{array}$ & $\begin{array}{c}\text { sign. } \\
\text { dist. } \\
\text { (4) }\end{array}$ & $\begin{array}{c}\text { all } \\
\text { dist. } \\
\text { (5) }\end{array}$ & $\begin{array}{c}\text { sign. } \\
\text { dist. } \\
\text { (6) }\end{array}$ \\
\hline \multicolumn{8}{|c|}{ a) portfolios } \\
\hline weighted & 0,33 & 0,32 & 0,43 & 0,40 & 0,32 & 0,25 \\
unweighted & 0,39 & 0,37 & 0,59 & 0,53 & 0,34 & 0,28 \\
\hline \multicolumn{8}{|c|}{ b) weights } \\
\hline weighted & 0,10 & 0,10 & 0,13 & 0,13 & 0,10 & 0,08 \\
unweighted & 0,12 & 0,14 & 0,18 & 0,17 & 0,10 & 0,09 \\
\hline
\end{tabular}




\section{Figures 1-3. Inter-industry significant differences}

Figures 1-3 show on the vertical axis the number of investing industries-pairs and on the horizontal axis the number of different coefficients. In figure 1 we consider US, in figure 2 and 3 we consider Canada and Italy, respectively. The test on the difference across coefficients is performed through a Wald test (10\% confidence level). The height of histograms represents the number of industry-pairs differing by the corresponding number of portfolio weights reported on the horizontal axis. Given the seven investing industries considered, we have 21 industry-pairs over which we test the difference among the corresponding portfolio coefficients (for instance, for US, we find that 8 industry-pairs out of 21 differ for 5 coefficients out of 10). We perform 210 tests: 21 industry-pairs times the 10 coefficients in each portfolio. The graphs also indicate the percentage of significant distances: $48 \%$ for US (101 out of 210), $44 \%$ for Canada and $28 \%$ for Italy.
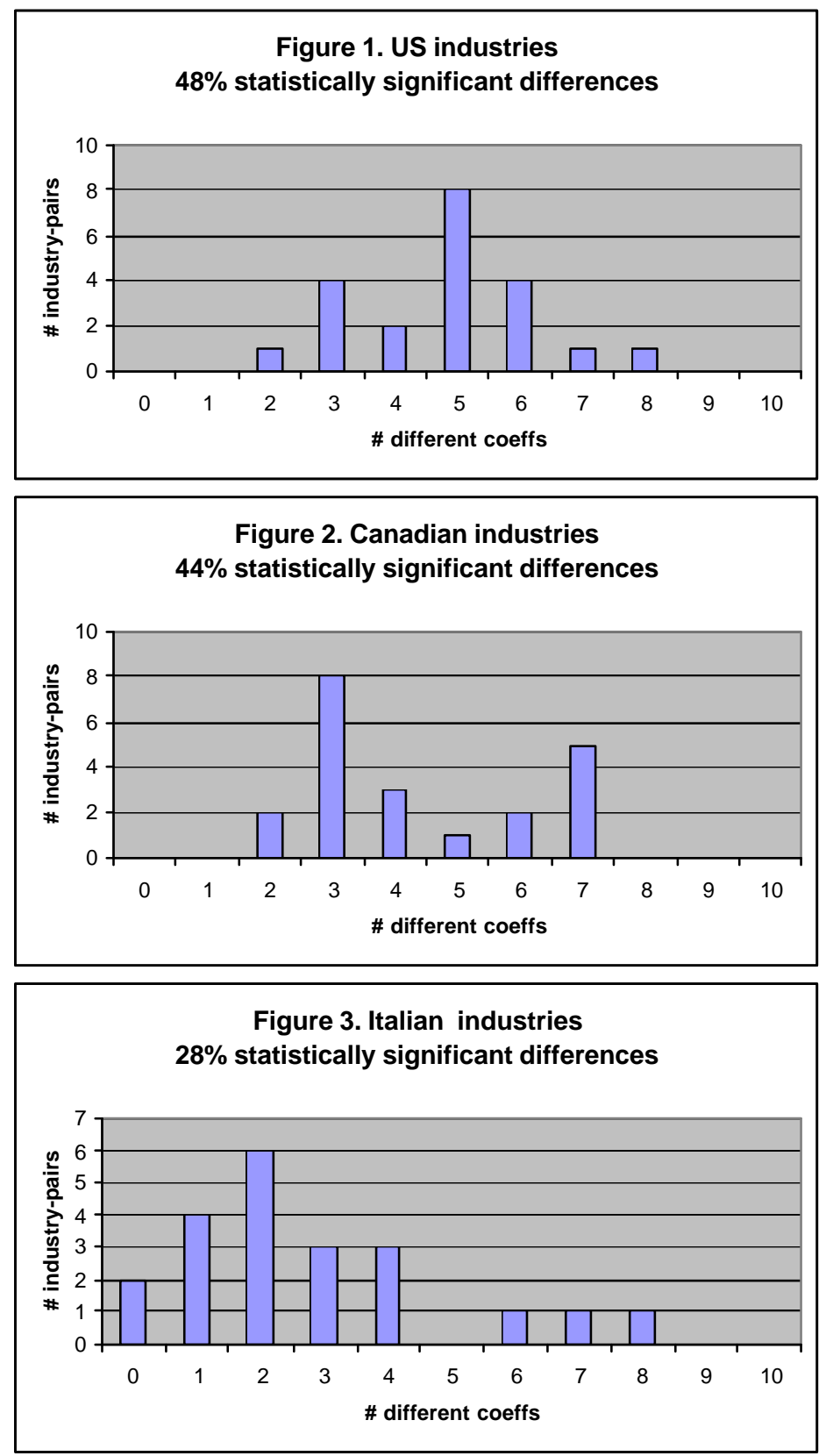
Our papers can be downloaded at:

$\underline{\text { http://cerp.unito.it/publications }}$

\section{CeRP Working Paper Series}

\begin{tabular}{|c|c|c|}
\hline $\mathrm{N}^{\circ} 1 / 00$ & Guido Menzio & Opting Out of Social Security over the Life Cycle \\
\hline $\mathrm{N}^{\circ} 2 / 00$ & $\begin{array}{l}\text { Pier Marco Ferraresi } \\
\text { Elsa Fornero }\end{array}$ & $\begin{array}{l}\text { Social Security Transition in Italy: Costs, Distorsions and (some) } \\
\text { Possible Correction }\end{array}$ \\
\hline$N^{\circ} 3 / 00$ & $\begin{array}{l}\text { Emanuele Baldacci } \\
\text { Luca Inglese }\end{array}$ & $\begin{array}{l}\text { Le caratteristiche socio economiche dei pensionati in Italia. } \\
\text { Analisi della distribuzione dei redditi da pensione (only available } \\
\text { in the Italian version) }\end{array}$ \\
\hline $\mathrm{N}^{\circ} 4 / 01$ & Peter Diamond & Towards an Optimal Social Security Design \\
\hline $\mathrm{N}^{\circ} 5 / 01$ & Vincenzo Andrietti & $\begin{array}{l}\text { Occupational Pensions and Interfirm Job Mobility in the } \\
\text { European Union. Evidence from the ECHP Survey }\end{array}$ \\
\hline $\mathrm{N}^{\circ} 6 / 01$ & Flavia Coda Moscarola & $\begin{array}{l}\text { The Effects of Immigration Inflows on the Sustainability of the } \\
\text { Italian Welfare State }\end{array}$ \\
\hline $\mathrm{N}^{\circ} 7 / 01$ & Margherita Borella & $\begin{array}{l}\text { The Error Structure of Earnings: an Analysis on Italian } \\
\text { Longitudinal Data }\end{array}$ \\
\hline $\mathrm{N}^{\circ} 8 / 01$ & Margherita Borella & $\begin{array}{l}\text { Social Security Systems and the Distribution of Income: an } \\
\text { Application to the Italian Case }\end{array}$ \\
\hline$N^{\circ} 9 / 01$ & Hans Blommestein & $\begin{array}{l}\text { Ageing, Pension Reform, and Financial Market Implications in } \\
\text { the OECD Area }\end{array}$ \\
\hline $\mathrm{N}^{\circ} 10 / 01$ & $\begin{array}{l}\text { Vincenzo Andrietti and Vincent } \\
\text { Hildebrand }\end{array}$ & $\begin{array}{l}\text { Pension Portability and Labour Mobility in the United States. } \\
\text { New Evidence from the SIPP Data }\end{array}$ \\
\hline$N^{\circ} 11 / 01$ & $\begin{array}{l}\text { Mara Faccio and Ameziane } \\
\text { Lasfer }\end{array}$ & $\begin{array}{l}\text { Institutional Shareholders and Corporate Governance: The Case } \\
\text { of UK Pension Funds }\end{array}$ \\
\hline $\mathrm{N}^{\circ} 12 / 01$ & Roberta Romano & $\begin{array}{l}\text { Less is More: Making Shareholder Activism a Valuable } \\
\text { Mechanism of Corporate Governance }\end{array}$ \\
\hline$N^{\circ} 13 / 01$ & Michela Scatigna & Institutional Investors, Corporate Governance and Pension Funds \\
\hline $\mathrm{N}^{\circ} 14 / 01$ & Thomas H. Noe & Investor Activism and Financial Market Structure \\
\hline $\mathrm{N}^{\circ} 15 / 01$ & Estelle James & $\begin{array}{l}\text { How Can China Solve ist Old Age Security Problem? The } \\
\text { Interaction Between Pension, SOE and Financial Market Reform }\end{array}$ \\
\hline$N^{\circ} 16 / 01$ & $\begin{array}{l}\text { Estelle James and } \\
\text { Xue Song }\end{array}$ & $\begin{array}{l}\text { Annuities Markets Around the World: Money's Worth and Risk } \\
\text { Intermediation }\end{array}$ \\
\hline $\mathrm{N}^{\circ} 17 / 02$ & $\begin{array}{l}\text { Richard Disney and } \\
\text { Sarah Smith }\end{array}$ & $\begin{array}{l}\text { The Labour Supply Effect of the Abolition of the Earnings Rule } \\
\text { for Older Workers in the United Kingdom }\end{array}$ \\
\hline $\mathrm{N}^{\circ} 18 / 02$ & Francesco Daveri & $\begin{array}{l}\text { Labor Taxes and Unemployment: a Survey of the Aggregate } \\
\text { Evidence }\end{array}$ \\
\hline $\mathrm{N}^{\circ} 19 / 02$ & $\begin{array}{l}\text { Paolo Battocchio } \\
\text { Francesco Menoncin }\end{array}$ & $\begin{array}{l}\text { Optimal Portfolio Strategies with Stochastic Wage Income and } \\
\text { Inflation: The Case of a Defined Contribution Pension Plan }\end{array}$ \\
\hline$N^{\circ} 20 / 02$ & Mauro Mastrogiacomo & Dual Retirement in Italy and Expectations \\
\hline $\mathrm{N}^{\circ} 21 / 02$ & $\begin{array}{l}\text { Olivia S. Mitchell } \\
\text { David McCarthy }\end{array}$ & Annuities for an Ageing World \\
\hline
\end{tabular}


Chris Soares Mark Warshawsky

$\mathrm{N}^{\circ} 23 / 02 \quad$ Ermanno Pitacco

$\mathrm{N}^{\circ}$ 24/02 Laura Ballotta Steven Haberman

$\mathrm{N}^{\circ} 25 / 02$ Edmund Cannon Ian Tonks

$N^{\circ} 26 / 02 \quad$ E. Philip Davis

$N^{\circ}$ 27/02 Reinhold Schnabel

$N^{\circ} 28 / 02 \quad$ Luca Spataro

N ${ }^{\circ} 29 / 02 \quad$ Marco Taboga

$\mathrm{N}^{\circ} 30 / 03 \quad$ Bas Arts

Elena Vigna

№ 31/03 Giacomo Ponzetto

N ${ }^{\circ} 32 / 04 \quad$ Angelo Marano

Paolo Sestito

$\mathrm{N}^{\circ} 33 / 04 \quad$ Elsa Fornero

Carolina Fugazza

Giacomo Ponzetto

N 34/04 Chourouk Houssi

$\mathrm{N}^{\circ}$ 35/04 Monika Bütler

Olivia Huguenin

Federica Teppa

$N^{\circ} 36 / 04 \quad$ Laurence J. Kotlikoff

$N^{\circ} 37 / 04 \quad$ Jay Ginn

№ 38/05 Carolina Fugazza

Federica Teppa

No 39/05 Anna Rita Bacinello

$N^{\circ} 40 / 05 \quad$ Carolina Fugazza

Massimo Guidolin

Giovanna Nicodano

$\mathrm{N}^{\circ}$ 41/05 Massimo Guidolin

Giovanna Nicodano

$\mathrm{N}^{\circ} 42 / 05 \quad$ Margherita Borella

Flavia Coda Moscarola

$\mathrm{N}^{\circ} 43 / 05 \quad$ John Beshears

James J. Choi

David Laibson

Brigitte C. Madrian
Annuity Risk: Volatility and Inflation Exposure in Payments from Immediate Life Annuities

Longevity Risk in Living Benefits

Valuation of Guaranteed Annuity Conversion Options

The Behaviour of UK Annuity Prices from 1972 to the Present

Issues in the Regulation of Annuities Markets

Annuities in Germany before and after the Pension Reform of 2001

New Tools in Micromodeling Retirement Decisions: Overview and Applications to the Italian Case

The Realized Equity Premium has been Higher than Expected: Further Evidence

A Switch Criterion for Defined Contribution Pension Schemes

Risk Aversion and the Utility of Annuities

Older Workers and Pensioners: the Challenge of Ageing on the Italian Public Pension System and Labour Market

A Comparative Analysis of the Costs of Italian Individual Pension Plans

Le Vieillissement Démographique :

Problématique des Régimes de Pension en Tunisie

What Triggers Early Retirement. Results from Swiss Pension Funds

Pensions Systems and the Intergenerational Distribution of Resources

Actuarial Fairness or Social Justice?

A Gender Perspective on Redistribution in Pension Systems

An Empirical Assessment of the Italian Severance Payment (TFR)

Modelling the Surrender Conditions in Equity-Linked Life Insurance

Investing for the Long-Run in European Real Estate. Does Predictability Matter?

Small Caps in International Equity Portfolios: The Effects of Variance Risk.

Distributive Properties of Pensions Systems: a Simulation of the Italian Transition from Defined Benefit to Defined Contribution The Importance of Default Options for Retirement Saving Outcomes: Evidence from the United States 


\begin{tabular}{|c|c|}
\hline $\mathrm{N}^{\circ} 44 / 05$ & Henrik Cronqvist \\
\hline $\mathrm{N}^{\circ} 45 / 05$ & Claudio Campanale \\
\hline $\mathrm{N}^{\circ} 46 / 05$ & $\begin{array}{l}\text { Annamaria Lusardi } \\
\text { Olivia S. Mitchell }\end{array}$ \\
\hline $\mathrm{N}^{\circ} 47 / 06$ & $\begin{array}{l}\text { Michele Belloni } \\
\text { Carlo Maccheroni }\end{array}$ \\
\hline $\mathrm{N}^{\circ} 48 / 06$ & $\begin{array}{l}\text { Onorato Castellino } \\
\text { Elsa Fornero }\end{array}$ \\
\hline $\mathrm{N}^{\circ} 49 / 06$ & Mariacristina Rossi \\
\hline $\mathrm{N}^{\circ} 50 / 06$ & $\begin{array}{l}\text { Andrea Buffa } \\
\text { Chiara Monticone }\end{array}$ \\
\hline $\mathrm{N}^{\circ} 51 / 06$ & Giovanni Mastrobuoni \\
\hline $\mathrm{N}^{\circ} 52 / 06$ & $\begin{array}{l}\text { Luigi Guiso } \\
\text { Tullio Jappelli }\end{array}$ \\
\hline $\mathrm{N}^{\circ} 53 / 06$ & Giovanni Mastrobuoni \\
\hline $\mathrm{N}^{\circ} 54 / 06$ & $\begin{array}{l}\text { Annamaria Lusardi } \\
\text { Olivia S. Mitchell }\end{array}$ \\
\hline $\mathrm{N}^{\circ} 55 / 06$ & Antonio Abatemarco \\
\hline $\mathrm{N}^{\circ} 56 / 07$ & $\begin{array}{l}\text { John A. Turner } \\
\text { Satyendra Verma }\end{array}$ \\
\hline$N^{\circ} 57 / 07$ & $\begin{array}{l}\text { Giovanni Mastrobuoni } \\
\text { Matthew Weinberg }\end{array}$ \\
\hline $\mathrm{N}^{\circ} 58 / 07$ & $\begin{array}{l}\text { Elisa Luciano } \\
\text { Jaap Spreeuw } \\
\text { Elena Vigna }\end{array}$ \\
\hline$N^{\circ} 59 / 07$ & $\begin{array}{l}\text { Riccardo Calcagno } \\
\text { Roman Kraeussl } \\
\text { Chiara Monticone }\end{array}$ \\
\hline $\mathrm{N}^{\circ} 60 / 07$ & $\begin{array}{l}\text { Riccardo Cesari } \\
\text { Giuseppe Grande } \\
\text { Fabio Panetta }\end{array}$ \\
\hline $\mathrm{N}^{\circ} 61 / 07$ & Irina Kovrova \\
\hline $\mathrm{N}^{\circ} 62 / 07$ & $\begin{array}{l}\text { Margherita Borella } \\
\text { Elsa Fornero } \\
\text { Mariacristina Rossi }\end{array}$ \\
\hline$N^{\circ} 63 / 07$ & Claudio Campanale \\
\hline$N^{\circ} 64 / 07$ & $\begin{array}{l}\text { Carlo Casarosa } \\
\text { Luca Spataro }\end{array}$ \\
\hline$N^{\circ} 65 / 07$ & Annamaria Lusardi \\
\hline
\end{tabular}

Advertising and Portfolio Choice

Increasing Returns to Savings and Wealth Inequality

Financial Literacy and Planning: Implications for Retirement Wellbeing

Actuarial Neutrality when Longevity Increases: An Application to the Italian Pension System

Public Policy and the Transition to Private Pension Provision in the United States and Europe

Examining the Interaction between Saving and Contributions to Personal Pension Plans. Evidence from the BHPS

Do European Pension Reforms Improve the Adequacy of Saving?

The Social Security Earnings Test Removal. Money Saved or Money Spent by the Trust Fund?

Information Acquisition and Portfolio Performance

Labor Supply Effects of the Recent Social Security Benefit Cuts: Empirical Estimates Using Cohort Discontinuities

Baby Boomer Retirement Security: The Roles of Planning, Financial Literacy, and Housing Wealth

On the Measurement of Intra-Generational Lifetime Redistribution in Pension Systems

Why Some Workers Don't Take 401(k) Plan Offers: Inertia versus Economics

Heterogeneity in Intra-Monthly Consumption. Patterns, SelfControl, and Savings at Retirement

Modelling Stochastic Mortality for Dependent Lives

An Analysis of the Effects of the Severance Pay Reform on Credit to Italian SMEs

La Previdenza Complementare in Italia:

Caratteristiche, Sviluppo e Opportunità per i Lavoratori

Effects of the Introduction of a Funded Pillar on the Russian Household Savings: Evidence from the 2002 Pension Reform

Does Consumption Respond to Predicted Increases in Cash-onhand Availability? Evidence from the Italian "Severance Pay"

Life-Cycle Portfolio Choice: The Role of Heterogeneous UnderDiversification

Rate of Growth of Population, Saving and Wealth in the Basic Life-cycle Model when the Household is the Decision Unit

Household Saving Behavior: The Role of Literacy, Information and Financial Education Programs 
No 66/07 Maarten van Rooij Annamaria Lusardi Rob Alessie

N ${ }^{\circ}$ 67/07 Carolina Fugazza

Maela Giofré

Giovanna Nicodano
Financial Literacy and Stock Market Participation

International Diversification and Labor Income Risk 